\title{
Interpretasi pada Gambar Anak Usia 8-12 Tahun yang Mengalami Stres Ringan
}

\author{
Priscilla Maharani ${ }^{*}$, Obed Bima Wicandra ${ }^{2}$, Rebbeca Milka $^{3}$ \\ 1,2,3 Program Studi Desain Komunikasi Visual, Fakultas Seni dan Desain, \\ Universitas Kristen Petra, Jl. Siwalankerto 121-131, Surabaya \\ * Penulis korespondensi; Email: priscilla.maharani@gmail.com
}

\begin{abstract}
Abstrak
Penelitian ini bertujuan untuk menginterpretasikan gambar anak usia 8-12 tahun yang mengalami stres ringan yang disebabkan oleh rasa marah, takut, dan bosan dan mengetahui gambar seperti apa yang dihasilkan. Penelitian ini berguna bagi para orang tua, guru, maupun peneliti lainnya agar bisa lebih memahami penggunaan elemen desain yang digunakan oleh anak untuk mengungkapkan perasaan mereka melalui media visual berupa gambar. Metode penelitian yang digunakan adalah grounded research. Sumber teori yang utama adalah data dari informan dan didukung teori-teori lainnya. Kesimpulannya adalah bahwa setiap elemen desain yang berkaitan dengan stres ringan memiliki peranan yang berbedabeda. Dalam menginterpretasikan elemen desain, teori yang digunakan adalah interpretasi menurut Terry Barrett yang diperkuat dengan semiologi Roland Barthes.
\end{abstract}

Kata kunci: Interpretasi, gambar, stres ringan, elemen desain.

\begin{abstract}
This study aims to interpre images of children aged 8-12 years who have experienced mild stress caused by moods of anger, fear, and boredom, and to know what kinds of images are produced. This study is useful for parents, teachers, and other researchers to understand more about the use of design elements that are used by children to express their feelings through visual media in the form of an image. This study uses a grounded research method. So, the primar source of theory is data from informants and other supporting theories. The conclusion is that each design element that is related to mild stress has a different role. The interpretation of design elements uses Terry Barrett's theory and is reinforced by the semiology of Roland Barthes's.
\end{abstract}

Keywords: Interpretation, images, mild stress, design elements.

\section{Pendahuluan}

Anak-anak adalah harta berharga bagi orang tua. Sebagai orang tua, biasanya akan selalu memberikan yang terbaik bagi anaknya. Tetapi banyak juga orang tua yang terkadang terlalu sibuk bekerja sehingga kurang memperhatikan kebutuhan mental anak. Kurangnya perhatian ini bisa membuat hubungan antara orang tua dan anak menjadi renggang atau malah buruk. Hubungan yang kurang baik ini akan menimbulkan tekanan (stres)

Tekanan (stres) bisa disebabkan karena beberapa hal, antara lain: marah, khawatir, takut, malu, bosan, bingung, jijik, lelah, frustasi, rasa bersalah, cemburu, merasa sendiri, sedih, terkejut, dan rasa curiga. Emosi atau mood yang disebutkan tadi merupakan hal yang sering ditemui dalam keseharian kita dan dalam hubungan kita dengan orang lain.

Menurut Ramijin, sebagian orang tua menunjukkan perasaan sayang dengan cara yang kurang tepat, sehingga kontraproduktif dan menimbulkan akibat yang kurang baik bagi perkembangan anak. Ia mencontohkan kewajiban anak untuk belajar tidak diimbangi porsi waktu bermain yang sesuai, sehingga menyebabkan anak menjadi jenuh dan stres dengan kondisi yang ada. Ramijin berkata bahwa jangan kira anak orang kaya tidak banyak yang bermasalah. Kurangnya pendidikan juga menimbulkan masalah bagi mereka, tetapi kurang kelihatan karena berlimpah materi ("Ketidaktahuan Orang Tua Sebabkan 'Generasi Stres”, 2011:par. $4,5,24)$.

Anak-anak yang masih banyak mendapat pengaruh orang tua ini bisa mengalami tekanan di dalam keseharian mereka yang akan berdampak buruk bagi pendidikan, sosial, maupun hubungan keluarga. Oleh karena itu, diharapkan sebagai orang tua bisa memahami anaknya melalui bahasa tubuh termasuk dalam visual atau gambar yang mereka buat saat mengalami tekanan.

Hasil dari interpretasi yang sudah ditinjau dari teori-teori desain diharapkan mampu memberikan sebuah pedoman bagi orang tua, pembimbing, 
maupun pengurus anak agar mereka mengerti kondisi dari anak tersebut melalui citra visual yang dihasilkan mereka. Sehingga dalam hubungan diantara mereka bisa berjalan dengan baik dan mengurangi resiko terjadinya stres, apalagi stres berat yang hampir ke arah depresi.

\section{Metode Penelitian}

Metode yang akan digunakan dalam mengumpulkan data primer melalui dua macam, yaitu nara sumber (survei, wawancara, observasi, dan dokumentasi) dan jurnal ilmiah. Sedangkan untuk data sekunder akan diambil dari buku-buku yang relevan dengan penelitian yang dilakukan dan mendukung dalam menganalisis data. Sedangkan data tersier akan diambil dari website dan artikel yang mungkin susah untuk didapatkan dalam kasus-kasus yang ada di surat kabar yang sudah lampau.

Metode yang dipakai dalam penelitian ini adalah grounded research. Metode ini beranjak dari fakta, dan dari fakta tanpa teori dicoba untuk mewujudkan sebuah teori. Dalam metode ini, data adalah sumber teori dan data yang diperoleh digunakan untuk mengembangkan teori yang menjelaskan hal-hal yang relevan. (Nazir, 2009:74)

Sampel yang diambil adalah anak-anak usia 8-12 tahun dengan jenis kelamin pria dan wanita. Kriteria anak yang penulis pilih adalah menengah ke atas dan anak ini tidak sedang mengikuti kursus menggambar. Sampel diteliti dalam waktu kurang lebih sekitar 2 sampai 3 minggu dan mendapatkan hasil yang bervariasi. Mereka adalah Jelly, Jim, Cece, Jane, dan Titi.

Dalam penelitian ini, metode yang akan digunakan dalam menganalisis data adalah kualitatif. Dengan cara mengumpulkan data, membaca seluruh data maupun informasi yang ada, mengkategorikan informasi, mengidentifikasi dan menyelidiki kondisi-kondisi tersebut, hingga pada penyajiannya dalam bentuk gambar, tabel, maupun uraian atau naratif.

\section{Interpretasi menurut Terry Barret dan Semiologi Roland Barthes}

Dalam menganalisis elemen-elemen desain, teori yang digunakan adalah teori interpretasi Terry Barrett dan diperkuat dalam pendeskripsian hasil interpretasi gambar berdasarkan tanda atau simbol yang sering dipakai dalam semiologi Roland Barthes.

\section{Interpretasi}

Prinsip-prinsip tentang interpretasi menurut Barrett adalah:
- Interpretasi adalah argumen-argumen yang sifatnya persuasif.

- Beberapa interpretasi lebih baik daripada interpretasi-interpretasi lainnya.

- Interpretasi yang baik adalah interpretasi yang berbicara lebih mengenai karya seni yang bersangkutan daripada mengenai kritikusnya.

- Feeling atau rasa adalah pedoman bagi penafsiran.

- Interpretasi-interpretasi atas satu karya seni yang sama bisa saja berlainan, bersaingan, bahkan bertentangan satu sama lain.

- Interpretasi-interpretasi sering didasarkan pada suatu pandangan dunia. Kita semua berjalan di dunia ini kurang-lebih dengan membawa suatu set asumsi yang terkonstruksi mengenai eksistensi, dan melalui set asumsi itulah kita menginterpretasi segala sesuatu termasuk karya seni. Ada kritikus yang punya pandangan dunia yang lebih konsisten dan diartikulasikan secara baik, misalnya yang didasarkan pada studi psikologi atau filsafat.

- Interpretasi yang baik memiliki keselarasan antara bentuk dan isi (koherensi), kesamaan atau kedekatan dan keterkaitan yang kuat (korespondensi), dan menginterpretasi secara menyeluruh/penuh (inklusif).

- Sebuah karya seni tidak harus seperti apa yang diinginkan oleh pembuat seni.

- Seorang kritikus seharusnya tidak menjadi juru bicara untuk seniman.

- Interpretasi seharusnya menghadirkan keadaan terbaik dari karya seni yang dikupas daripada keadaan terburuknya.

- Objek-objek interpreasi adalah karya-karya seni, bukan senimannya.

- Semua karya seni mengandung sesuatu yang berkenaan dengan dunia/keadaan di mana karya itu muncul.

- Semua karya seni mengandung sesuatu dalam dirinya yang berkaitan dengan atau mengenai karya seni lain.

- Tidak ada satupun interpretasi yang bisa sepenuhnya merengkuh makna dari suatu karya seni.

- Makna karya seni boleh jadi berbeda dari signikansi mengenai karya itu sebagaimana ditangkap oleh seorang penonton

- Interpretasi pada akhirnya merupakan suatu upaya komunal, dan komunitas yang pada akhirnya sebenarnya mengkoreksi diri.

- Interpretasi yang baik mengundang kita untuk menginterpretasi karya yang bersangkutan menurut interpretasi kita sendiri.

(Barrett, 1994) 


\section{Semiologi}

Ringkasan mengenai teori semiologi a la Barthes pada bukunya yang berjudul Elements of Semiology akan memperjelas penggunaan teori ini. Teori Barthes banyak membahas dan berbicara mengenai mitos. Mitos dalam teori Barthes adalah "cara pemaknaan" yang menjadi pegangan atas tandatanda yang ada dan berfungsi sebagai penanda. Mitos ini menggambarkan situasi sosial budaya maupun politik yang diterima apa adanya pada satu masa dan mungkin tidak untuk masa yang lain.

Selain mitos, Barthes membagi makna menjadi dua tingkatan, yaitu makna denotasi dan makna konotasi. Kedua tingkatan ini memiliki perbedaan mendasar dan rumus yang berbeda.

Tingkatan makna pertama adalah denotasi. Denotasi adalah makna yang digunakan untuk mendeskripsikan makna secara definisional, literal, gamblang atau pengertian umum dari sebuah tanda.

Tingkatan makna kedua adalah konotasi. Konotasi merupakan penggunaan makna yang lebih luas dan dalam dengan adanya kiasan atau metafora yang memiliki karakter umum, global, dan menghasilkan fragmen ideologis (budaya, sejarah, pengetahuan). Makna konotasi mengacu pada asosiasiasosiasi budaya sosial dan personal berupa ideologis, emosional dan lain sebagainya. Konotasi identik dengan ideologi, yang disebut sebagai 'mitos' dan berfungsi untuk mengungkapkan dan memberikan pembenaran bagi nilai-nilai yang berlaku dalam suatu periode tertentu. Mitos dibangun oleh suatu rantai pemaknaan yang telah ada sebelumnya atau dengan kata lain, mitos adalah juga suatu sistem pemaknaan tataran kedua. Di dalam mitos pula sebuah petanda dapat memiliki beberapa penanda.

Ada tingkatan ketiga dalam Barthes yaitu "ideologi” sebagai bentuk penanda konotasi. Ideologi ini pada hakikatnya merupakan suatu sistem kepercayaan yang dibuat-buat dengan kesadaran semu yang pada akhirnya mempengaruhi individu untuk membentuk sebuah orientasi sosial dan berperilaku sesuai dengan ideologi tersebut. Ideologi ini bersembunyi dibalik mitos. (Barthes, 1973)

\section{Analisis Hubungan Elemen Desain dengan Mood Marah}

Untuk mengetahui kecenderungan anak usia 8-12 tahun dalam penggunaan elemen desain (garis, bentuk, dan warna) di saat mood mereka marah, maka akan ditampilkan dalam bentuk tabel agar lebih mudah dibaca. Pada tabel 1 berisi hubungan antara elemen desain dengan mood marah secara keseluruhan dari informan yang ada.

Tabel 1. Hubungan elemen desain dengan moodmarah

\begin{tabular}{ll}
\hline Garis & Lurus \\
Bentuk & Persegi (1) dan lingkaran (2) \\
Warna & Merah, jingga, coklat muda, biru dan hitam (1) \\
& Kuning, biru muda, krem, dan coklat (2) \\
\hline
\end{tabular}

\section{Keterangan:}

(1) : Sering muncul dan digunakan

(2) : jarang muncul dan digunakan

Apakah Anda pernah mendengar kata-kata, "terbakar oleh api kemarahan" yang mungkin saja diucapkan oleh teman kita sendiri atau bahkan keluarga kita? Kata-kata ini muncul bukan sebagai sesuatu yang kebetulan dan tanpa makna. Katakata ini mengindikasikan bahwa marah itu berhubungan dengan api. Dan jika kita berbicara tentang api, maka yang muncul di benak kita adalah panas, kebakaran, dan asap.

Lalu, apakah Anda juga pernah mendengar orang yang mengatakan bahwa dia akan meledak atau pecah karena sudah terlalu lama menahan 'sesuatu' di dalam dirinya? Biasanya orang akan berkata, "udah di ubun-ubun ini, udah mau meledak" saat mereka marah. Oleh karena itu emosi yang berlebihan bisa membuat pembuluh darah kita "pecah" sehingga terjadi penyakit yang kita kenal, yaitu stroke.

Dari ungkapan-ungkapan di atas mengenai marah, maka bisa disimpulkan bahwa marah itu berhubungan dengan panas, api, terbakar, asap, ledakan, kepala, darah, dan pecah.

Ada banyak hal menarik yang digambarkan dalam karya komik untuk menggambarkan seorang tokoh marah. Gambar tersebut memiliki hubungan antara elemen desain dengan mood marah yang digambarkan atau yang sudah merupakan kesepakatan (konvensi). Sebagai contoh adalah penggambaran dalam visualisasi berikut ini.

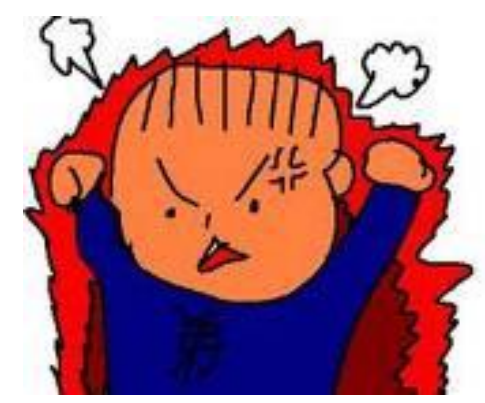

Sumber: http://ziainside.blogspot.com/2011/01/sebelu m-marah-marah-baca-dulu-yang.html

Gambar 1. Ekspresi marah 1 


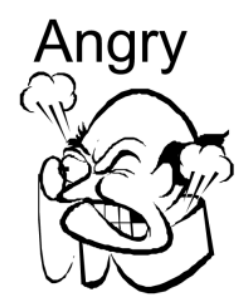

Sumber: http://uniquebanget.blogspot.com/2010_01_01_ archive.html

Gambar 2. Ekspresi marah 2

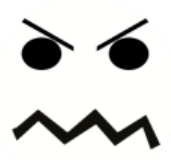

Sumber: http://delu9gaziru.blogspot.com/2010_11_01_ archive.html

Gambar 3. Ekspresi marah 3

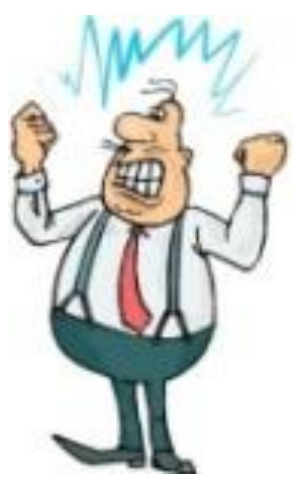

Sumber: http://ghozin16.wordpress.com/2008/08/02/ tipsmengatasi-marah/

Gambar 4. Ekspresi marah 4

Pada gambar-gambar di atas, dapat dijelaskan elemen-elemen desain yang digunakan sebagai ungkapan atau luapan perasaan marah. Garis yang digunakan saat marah adalah garis-garis diagonal, zigzag, vertikal dan lengkung. Garis yang cenderung digunakan adalah garis diagonal dan zigzag.

Bentuk-bentuk yang banyak digambarkan saat marah adalah bentuk segitiga dan persegi. Bentuk ini bukan dilihat yang secara nyata, tetapi dari bentuk mulut tokoh, di mana pada gambar 1 bentuk mulutnya terlihat segitiga dan gambar 4 terlihat seperti persegi.

Dari elemen bentuk tersebut, maka ada hubungan antara tingkat kemarahan dan warna yang digunakan. Pada gambar 1 di mana tokoh tersebut terlihat sangat marah karena ada api-api di sekitarnya dan urat di kepalanya, alis yang terangkat, tangan yang mengepal, dan asap yang dikeluarkan. Kemarahan ini terllihat sudah mencapai tingkat yang tinggi. Ternyata di saat marah dengan tingkatan yang tinggi, bentuk mulut yang digambarkan adalah segitiga, sedangkan warna yang digunakan adalah warna-warna panas, yaitu merah dan jingga. Keseluruhan gambar 1 juga memberikan kesan panas.

Berikutnya dalam gambar 4 bentuk mulutnya memiliki bentuk dasar persegi, yaitu persegi panjang. Pada gambar ini, tokoh tersebut terlihat marah dan geram yang masih dalam tingkatan yang ringan. Dari sini bisa diinterpretasikan bahwa saat itu, perasaan yang dialami adalah marah ringan karena melihat bahwa tanda-tanda kemarahannya hanya terlihat dari mulutnya, tangan yang mengepal dan garis zigzag, berbeda dengan gambar 1 yang sebelumnya. Tingkat marah yang masih tergolong rendah menghasilkan bentukan yang lebih smooth yang terlihat dari mulutnya dan menggunakan warna-warna netral dan dingin, yaitu warna putih, abu-abu, dan biru muda.

Dari sini, saya melihat bahwa di saat orang merasa marah, mitos-mitos yang muncul di dalam penggunaan gambar dan simbol adalah sebagai berikut:

- Garis yang digunakan cenderung diagonal dan zigzag.

- Bentuk yang cenderung digunakan adalah bentuk segitiga saat marah dengan level yang tinggi, dan persegi untuk level kemarahan yang lebih rendah.

- Warna dominan yang digunakan adalah warna panas, yaitu merah dan jingga. Tetapi tidak menutup kemungkinan menggunakan warna netral dan dingin, yaitu warna putih, abu-abu, dan biru muda.

- Simbol kemarahan di sini ada beberapa, yaitu api, asap, urat, gigi, tangan yang mengepal, dan mata melotot yang nyaris keluar.

\section{Pembahasan Penggunaan Garis Saat Mood Marah}

Garis diagonal adalah garis yang mengesankan ketidakseimbangan dan terkesan seperti mau jatuh. Jika dikaitkan dengan emosi, maka emosi yang labil atau tidak stabil dan juga mental yang akan jatuh. Menurut Feldman, penggunaan diagonal ini juga terkait dengan emosi yang tak terkontrolEmosi yang tak terkontrol itu bisa bermacam-macam termasuk marah. Garis vertikal yang melambangkan kekerasan dan kekuatan juga biasa digunakan saat orang merasa marah. Di mana saat terjadi kekerasan, maka garis inilah yang digunakan. Lalu garis zigzag juga merupakan garis yang banyak digunakan untuk menggambarkan kemarahan seperti penjelasan di atas. Jadi, garis yang seharusnya menggambarkan dan cenderung digunakan oleh anak saat mereka marah 
adalah garis diagonal dan zigzag. Garis diagonal termasuk ke dalam garis lurus dan garis zigzag ke dalam garis majemuk.

Dalam suatu realita sosial, orang yang marah seringkali mengepalkan tangannya erat-erat untuk menahan amarahnya yang akan meledak. Sama seperti saat menggambar, di mana saat marah maka pensil atau alat gambar lainnya akan ditekan sehingga menimbulkan goresan yang sangat kuat karena dia menahan amarahnya dan mengeluarkannya dengan tekanan di dalam bidang gambar. Sehingga goresan maupun pewarnaannya terasa kuat dan kasar. Saat memperhatikan garis yang digunakan pada saat marah berupa garis lurus, maka jika diteliti lagi lebih dalam ke setiap gambar anak yang marah maka akan ditemukan bahwa garis lurus yang dipakai saat marah adalah campuran antara garis diagonal, vertikal, dan horizontal.

Jika menganalisis garis yang digunakan pada sampel secara mendetail lagi, maka yang menarik untuk dibahas adalah penggunaan garis horizontal pada gambar sampel. Horizontal memiliki makna tenang, damai, dan tidur yang berlawanan dengan emosi marah yang tidak tenang, tak ada kedamaian dan selalu ada perasaan meluap-luap. Sekarang akan dibahas mengapa ada yang menggunakan garis tersebut.

Melihat penyebabnya, maka disana ada unsur bosan, lelah, dan ingin istirahat. Informan memang marah karena harus melakukan sesuatu yang seharusnya tidak perlu dia lakukan saat itu. Perasaannya itu bercampur baur, sehingga garis yang dominan digunakan malah horizontal, di mana menceritakan keinginan informan saat itu, teteapi kemarahnnya terlukiskan dari pemilihan warna yang digunakan.

Dari sini akan terlihat bahwa memang teori yang diutarakan tidak selalu cocok dengan realita yang terjadi. Garis-garis bisa digunakan sesuka mereka tergantung dari sudut pandang mana mereka melihat sebuah elemen.

\section{Pembahasan Penggunaan Bentuk Saat Mood Marah}

Pada mitos yang sebelumnya dibahas, maka seharusnya anak-anak cenderung menggunakan bentuk segitiga sebagai bentuk yang dominan dan persegi sebagai bentuk marah yang tingkatnya lebih rendah. Bentuk mewakili kemarahan mereka dalam tingkatan yang berbeda.

Sekarang akan dibahas hasil penelitian di mana pada saat anak merasa marah, maka bentuk yang paling banyak muncul adalah persegi. Bentuk persegi ini lebih banyak muncul sebagai bentuk yang dominan digunakan. Jika bentuk persegi ini dimaknai, maka bisa memberikan gambaran bahwa mereka memang marah, tetapi masih dalam tingkatan yang rendah.

Pembahasan lainnya adalah mengenai penggunaan bentuk lain, yaitu lingkaran. Ada anak yang saat marah, ternyata menggambarkan bentuk lingkaran yang lebih ke arah oval dan tidak beraturan. Bentuk lingkaran yang seharusnya memiliki makna yang kontras dengan marah ternyata juga digunakan saat marah, tetapi di dalam case tertentu sebagai tanda bahwa di dalam kemarahannya, dia masih memiliki kepercayaan secara spiritual untuk tetap memiliki kasih walaupun dalam kondisi marah. Kemungkinan ini bisa terjadi karena memang ada anak yang di didik oleh orang tua untuk mereka mengasihi saudaranya sendiri, khususnya dalam hal mengalah kepada adiknya yang lebih kecil. Bentuk lingkaran yang dibuat memang tidak sempurna, di mana diartikan sebagai pengampunan atau kasih yang masih tercampur dengan rasa marah mereka.

Dari sini muncullah ideologi, bahwa saat seseorang merasa marah, maka bentuk yang digunakan bukanlah segitiga, tetapi persegi di mana memiliki makna keseimbangan di dalam berperilaku dan juga terasa adanya sesuatu yang membatasi. Saat marah, mereka masih memikirkan perilaku mereka pada orang lain dan membatasi marah agar tidak berlebihan untuk masalah yang memang tingkatan emosinya masih rendah. Selain itu marah juga bisa digambarkan dengan bentuk lingkaran yang lebih mengarah bentuk oval dan tidak beraturan.

Melihat hal tersebut, maka muncullah suatu pemikiran bahwa perasaan marah tidak hanya bisa digambarkan di dalam bentuk segitiga maupun persegi, tetapi juga bisa ke dalam bentuk lingkaran yang memiliki makna yang kontras, tergantung dari didikan orang tua, lingkungan, agama, dan kepercayaan mereka. Di sini juga terlihat bahwa mereka masih banyak menggambarkan secara denotatif sehingga bentuk saja tidak cukup untuk menerangkan perasaan mereka. Bisa saja mereka lebih suka mengungkapkan perasaan mereka lewat warna, garis atau goresan, ruang kosong, simbol, dan ekspresi wajah.

\section{Pembahasan Penggunaan Warna Saat Mood Marah}

Di saat orang marah, maka akan dihubungkan dengan api sebagai simbol kemarahan. Api ini jika 
digali lagi lebih dalam maka akan muncul perasaan "panas" yang bisa dihubungkan dengan penggunaan warna, yaitu menggunakan warna panas. Oleh karena itu, saat orang merasa marah maka warna yang akan dipilih adalah warna-warna panas, khusunya merah dan jingga. Ini adalah sebuah mitos yang mana di saat orang merasa marah, maka akan berhubungan erat dengan warna-warna panas, khusunya warna merah. Menurut Dameria, warna merah secara negatif melambangkan panas, bahaya, emosi yang meledak, agresif, dan brutal (Dameria, 2007:44).

Mengenai warna yang digunakan saat merasa marah, maka akan terlihat dari hasil gambar informan di mana saat marah memang cenderung menggunakan warna-warna panas, khusunya warna merah dan jingga. Di sini akan dijelaskan interpretasi mengenai marah terhadap elemen warna. Warna yang digunakan saat marah pada sampel jika dilihat secara keseluruhan memilih warna-warna panas, yaitu merah dan jingga. Sedangkan warna lainnya yang banyak digunakan adalah warna dari keluarga coklat dan keluarga biru.

Warna merah memang memiliki efek emosional yang lebih kuat dibandingkan warna lainnya dan paling menarik perhatian. Warna ini secara negative diasosiasikan sebagai api, kemarahan, darah, bahaya, peringatan, peperangan, ketidaksabaran, perselisihan, dan kebencian. tidak heran jika saat marah, maka orang menggunakan warna ini untuk melukiskan emosi mereka.

Warna lainnya yang banyak digunakan adalah warna jingga. Warna jingga merupakan pencampuran antara warna merah dan kuning. Dengan kata lain, makna negatif dari warna campuran ini adalah dominan, pasif, arogan, ketidaktahuan, melempem, ambisius, nafsu, manipulasi, kejahatan, berbahaya, dan kematian. Keluarga coklat ini juga memiliki makna depresi yang akan dialami jika kita sedang marah yang tidak dilepaskan, tetapi tertahan. Lalu keluarga biru juga memberikan kesan diam, kesedihan, dingin, dan tidak akrab di dalam gambar yang kondisinya dalam keadaan marah.

Ada beberapa informan yang menarik untuk dibahas sehubungan dengan marah. Pertama adalah pemilihan warna yang digunakan secara urutan percakapan adalah kuning, jingga, merah, dan hijau muda. Di sini akan digambarkan sedikit alurnya yang nantinya akan diterangkan maknanya.

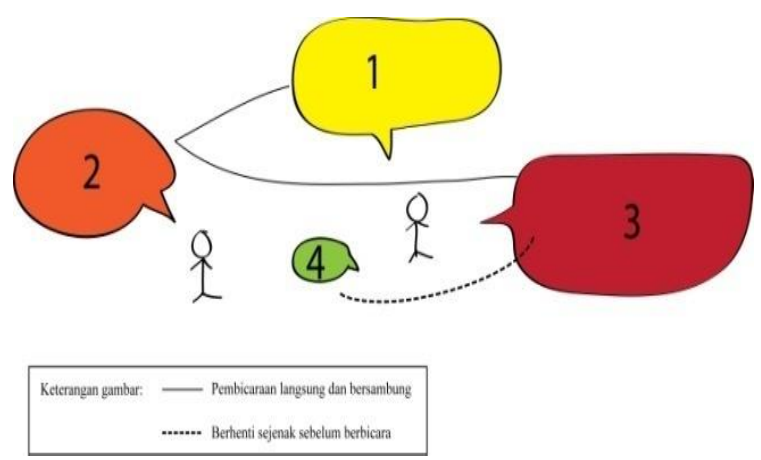

Gambar 5. Gambar proses kemarahan

Warna merah memang memiliki makna negatif seperti api, kemarahan, bahaya, peringatan, ketidaksabaran, perselisihan, jahat, dosa, dan kebencian. Lalu kita melihat juga warna kuning di mana memiliki arti bahaya, peringatan, dan tidak stabil. Dan warna jingga memiliki makna negatif sebagai ketidaktahuan, kejahatan, manipulasi, pasif, dan makna positifnya adalah keberanian. Pembahasan gambar 5. ini akan dijelaskan berikut ini.

Gambar tersebut memperlihatkan sebuah percakapan antara dua orang yang dibuat di dalam balon kata. Balon kata yang pertama diwarnai dengan kuning di mana perasaanya sedang tidak stabil karena baru saja pulang dari sekolah dan saat mencari barang miliknya, tidak ditemukannya sehingga dia memiliki kecurigaan dan keyakinan bahwa adiknya yang mengambilnya dan bertanya kepada adiknya.

Lalu beranjak pada balon kata kedua yang berwarna jingga yang bisa diartikan bahwa jingga ini berarti berani dan nafsu. Berani dan nafsu ini bisa terlihat dari cerita anak ini.

Balon kata ketiga menceritakan perasaan yang muncul ketika mereka melewati percakapan, yaitu perasaan marah dan rasa tidak suka. Marah karena tahu bahwa kenyataannya yang mengambil barangnya adalah adiknya dan barang tersebut sudah tinggal sedikit. Perasaan yang awalnya berwarna kuning sekarang berubah menjadi warna merah pada percakapan selanjutnya, mengapa? Karena yang tadinya masih labil dan curiga yang dalam arti belum tau dengan jelas siapa yang mengambil walaupun sudah yakin, setelah tau kebenarannya bahwa memang adiknya yang mengambil dan sepertinya merasa tak bersalah membuat anak ini berada di puncak kemarahan. Kemarahan yang sudah tinggi ini terlihat dari warna yang digunakan, yaitu merah. Warna merah ini memiliki arti kemarahan, api, perselisihan, dan benci. 
Yang menarik adalah balon kata keempat, yaitu warna hijau muda dengan ukuran yang kecil dan tidak dominan. Balon kata ini muncul di saat anak ini mulai reda amarahnya, tetapi masih ada rasa kesal di hatinya karena insiden tersebut. Warna hijau muda ini melambangkan cemburu, iri hati, dan yang postif adalah ketenangan. Jadi warna ini dibuat dalam ukuran kecil saja digunakan karena perasaan Jane sudah lebih tenang, tetapi masih ada rasa kesal yang terlihat dari tulisan di dalamnya.

Ada informan yang berbeda dalam hal penggunaan warna dibandingkan informan yang lain, yaitu menggunakan warna biru sebagai warna yang mendominasi dan warna yang terlihat secara hierarki adalah warna hitam. Hierarki di sini dalam arti point of view warna di dalam gambar tersebut.

Warna yang mendominasi memang biru karena menggambarkan warna langit yang berwarna biru langit ini masih bermain di area denotatif. Sedangkan warna hitam yang digunakan juga masih bermain di area denotatif walaupun perasaannya terlihat diwarnai dengan warna krem yang bercampur dengan warna hitam. Kesan yang timbul adalah kesedihan dan suram. Dari sini akan terlihat bahwa kemarahannya bukan kemarahan yang meledak-ledak, tetapi kemarahan yang membuatnya kecewa dan putus asa.

Melihat gambar marah yang dibuat oleh anak-anak saat marah ini akan terpikir bahwa warna memang menunjukkan perasaan mereka, tetapi bukan warna merah dan jingga saja yang bisa menceritakan perasaan marah mereka, tetapi juga warna lain, yaitu warna pastel dan netral. Warnawarna yang dicampurkan dan dikombinasi memang bisa menghasilkan suatu perasaan tertentu. Jadi, pemilihan warna ini bukan hanya sekedar ajang untuk meluapkan perasaan marah mereka, tetapi juga menyampaikan akibat dan perasaan yang terjadi setelah marah, penggambaran suasana pasca-marah. Maksudnya adalah perasaannya setelah marah adalah sedih dan kecewa.

Mitos warna ternyata memang berlaku untuk mood marah, tetapi tidak berlaku untuk beberapa kasus lainnya di mana mereka bisa memilih warnawarna netral ataupun pemilihan warna yang kontras sekali dengan mitos menggunakan warna panas, yaitu memilih warna-warna yang dingin. Jadi warna-warna panas memang bisa mewakili perasaan marah, tetapi tidak selalu menceritakan mengenai mood "marah" itu sendiri karena marah itu sendiri memiliki artian yang sangat luas dan dalam, tergantung dari penyebabnya.

\section{Analisis Data Bentuk Hubungannya dengan Mood Takut}

Ketakutan adalah sebuah perasaan yang muncul di dalam diri kita yang berpotensi membahayakan diri kita, seperti rasa sakit, terabaikan, tidak dihargai, dihina, terluka, bahkan kematian. Perasaan-perasaan ini yang membuat orang sering merasa takut dan bisa juga berakibat fobia pada diri kita. Jadi, rasa takut bisa muncul karena segala sesuatu yang membahayakan atau mengancam diri kita, merasa asing, dan kehilangan sesuatu. Ketakutan ini juga berhubungan dengan kecemasan, karena dua emosi ini saling berhubungan dan terkait (Mendatu, 2009).

Tabel 2. Hubungan elemen desain dengan mood takut

\begin{tabular}{ll}
\hline & \multicolumn{1}{c}{ Takut } \\
\hline Garis & Lurus (1), lengkung dan majemuk (2) \\
Bentuk & Persegi (1) dan lingkaran (2) \\
Warna & Hitam dan putih (1) \\
& Merah, jingga, kuning, dan hijau muda (2) \\
\hline Keterangan: \\
(1) : Sering muncul dan digunakan \\
(2) : jarang muncul dan digunakan
\end{tabular}

Pada saat seseorang merasa takut, reaksi yang muncul bisa bermacam-macam, seperti gemetar, gugup, kata-katanya menjadi kacau balau, sering salah ucap, bulu kuduk merinding, tertunduk, terdiam, dan kabur. Dari reaksi yang muncul dan perasaan-perasaan yang timbul saat rasa takut, maka saya bisa memberikan sebuah gambaran umum mengenai rasa takut ini.

Di saat orang merasa takut, garis yang dibuat biasanya adalah garis lengkung dan diagonal yang memiliki kesan berlari dan kabur. Dalam realitas sosial mengenai respon orang ketika merasa takut adalah kabur yang biasanya disertai dengan lari. Oleh karena itulah kemudian ada ungkapan seperti, misalnya "lari dari kenyataan" yang menunjukkan adanya perasaan takut. Selain itu ada garis zigzag yang memaknai ada sesuatu yang berbahaya, sehingga orang yang merasa bahaya bisa saja memberikan tanda berupa garis zigzag.

Ada realita yang sering muncul sehubungan dengan rasa takut. Di saat orang gemetar karena takut, maka akan terlihat goresannya putus-putus atau terlihat tidak langsung menyambung karena biasanya tangan yang gemetar tidak akan menghasilkan gambar yang halus, tetapi sedikit bergerigi. Oleh karena itu garis yang terlihat jadi seperti zigzag.

Orang yang takut juga suka dengan "melarikan diri" dari masalah yang dialaminya sehingga mereka menjadi berbalik dan tak mau melangkah 
maju ke depan lagi. Garis diagonal menggambarkan bahwa mereka menuruni jalan yang sudah dilaluinya. Begitu juga dengan garis lengkung di mana mereka berbelok ke arah yang berlainan.

Penyebab takut karena merasa adanya bahaya terlihat dari bentuk segitiga. Bentuk segitiga ini merupakan sebuah lambang "bahaya" yang sudah disepakati secara universal oleh dunia. Kita sering melihat bentuk segitiga di dalam rambu-rambu adalah tanda peringatan bahaya. Oleh karena itu, tanda segitiga memang menggambarkan "bahaya" yang menyebabkan ketakutan dan kewaspadaan. Jadi bentuk segitiga bisa memberikan kesan takut kepada orang.

Lalu bagaimana dengan warna? Ketakutan selalu digambarkan di dalam suasana yang mencekam, suram, dan gelap. Warna-warna yang cenderung digunakan saat orang merasa takut cenderung warna-warna gelap, permainan warna hitamputih, kelabu yang dicampur dengan warna-warna gelap seperti hijau pupus, merah, coklat yang terkesan konservatif. Warna hitam memang memberikan kesan keadaan yang tidak bersahabat, ancaman, kaku, sengsara, putus asa, dan kesepian. Warna putih memberikan kesan dingin sehingga terasa menggigil dan tidak siap. Warna kelabu memberi kesan kuno, lemah, dan kehabisan energi. Warna merah mengesankan adanya bahaya, peringatan, dan tekanan. Sedangkan warna coklat mengesankan depresi dan konservatif.

Ada beberapa gambar yang berhubungan dengan rasa takut. Pada gambar ini terlihat bahwa penjelasan di atas tersebut memiliki sebuah kesepakatan yang disepakati oleh masyarakat (konvensi) untuk menggambarkan kondisi atau situasi takut.
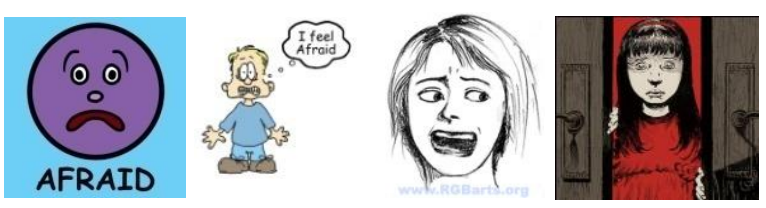

Sumber: http://cechgentong.multiply.com/journal/item/ 459/Takutlah_Kepada_Tuhan_Bukan_Kepada_Hantu http://krizz07.blogspot.com/2010/09/i-am-not-afraid.html http://www.rgbarts.com/ExpressionsAfraidAnnnoyed.sht $\mathrm{ml}$; http://www.ugo.com/movies/comic-con-2010-dont-beafraid-of-the-dark-footage

Gambar 6. Berbagai versi gambar ketakutan

Mitos-mitos di sini berhubungan dengan sebuah elemen desain sebagai sebuah tanda konvensional, antara lain:

- Garis yang digunakan cenderung diagonal, lengkung, dan zigzag.
- Bentuk yang cenderung digunakan adalah bentuk segitiga yang merupakan perlambangan dari rasa bahaya yang dihadapi.

- Warna dominan yang digunakan adalah warnawarna gelap dan suram, seperti hitam-putih, abu-abu, dan coklat.

\section{Pembahasan Penggunaan Garis Saat Mood Takut}

Ternyata kecenderungan pemakaian garis saat informan merasa takut adalah garis lurus. Garis lurus yang digunakan cenderung garis vertikal dan horizontal. Hasilnya berlainan dengan mitos yang seharusnya menggunakan garis zigzag, diagonal, dan lengkung. Tetapi jika dilihat secara keseluruhan, pada gambar para informan hanya ada satu saja yang memiliki bermacam-macam garis di dalamnya, sedangkan dua informan lainnya cenderung vertikal dan horizontal saja.

Yang akan dibahas adalah satu informan yang hanya menggunakan garis vertikal dan horizontal, dan sedikit diagonal. Garis vertikal dan horizontal yang bertumpukan membentuk tanda salib memiliki makna adanya kekuatan dan ketegaran hati. Garis diagonal ini memiliki kesan adanya sebuah harapan di dalam ketidakpastian.

Garis horizontal yang banyak digunakan memiliki kesan sepi dan tenang. Yang terlihat adalah saat informan merasa takut, maka keinginannya adalah keadaan yang sepi tanpa orang. Karena ketakutan mereka akan orang lain sehingga mereka tidak ingin orang tersebut muncul dengan segera karena ingin menikmati saat-saat yang tenang.

Sebenarnya dari gambar-gambar yang dihasilkan oleh informan saat mereka merasa takut, penggunaan garis kurang memiliki kesan yang mendalam sesuai dengan mood mereka saat itu. Tetapi elemen lainnya yang lebih menonjolkan mood mereka. Elemen lain ini akan dibahas di sub-bab berikutnya.

\section{Pembahasan Penggunaan Bentuk Saat Mood Takut}

Bentuk yang dibuat saat takut kebanyakan adalah persegi. Persegi ini memiliki mitos yang mungkin bisa menjadi ideologi pada informan. Saat takut, bentuk yang seharusnya cenderung digunakan adalah segitiga, sedangkan hasil data dari penelitian tidak ada anak yang menggunakan bentuk segitiga. Bentuk persegi yang digunakan biasanya adalah persegi panjang. Secara mitos, bentuk segitiga memang dipahami sebagai makna ketakutan. Namun bentuk persegi panjang juga 
bisa dipahami sebagai rasa takut. Secara realita sosial, bentuk persegi panjang juga identik dengan bentuk peti mati yang menggambarkan kesedihan karena kehilangan seseorang atau perilaku khusus seperti fobia terhadap ruang yang berbentuk persegi. Di sini secara tidak sadar informan menggunakan persegi untuk mengungkapkan rasa takut mereka.

Persegi memiliki makna antara lain, adanya batasan, benda, tanah, statis, dan kematian. Jika anak dominan menggunakan persegi di saat menggambar, maka perasaannya saat itu adalah marah dan kesal.

\section{Pembahasan Penggunaan Warna Saat Mood Takut}

Warna bisa menceritakan perasaan yang kita alami, seperti rasa takut yang kita alami biasanya menggunakan warna-warna suram, yaitu hitamputih, abu-abu, dan coklat. Perpaduan dari warnawarna yang gelap dan suram biasanya menggambarkan suasana yang "tidak enak" dan juga perasaan takut.

Di saat perasaan takut itu muncul, maka para informan cenderung menggunakan warna hitam dan putih. Warna yang informan gunakan memiliki kesan ada perasaan yang mendalam, di mana ia merasa takut akan sesuatu yang berakibat tidak baik untuk dirinya. Perasaan ini memang terlihat dari penggunaan warna pada gambar. Tetapi walaupun informan cenderung menggunakan warna hitam dan putih sesuai dengan mitos yang ada, tetapi ada juga informan yang memilih hanya satu warna saja saat takut, yaitu kuning.

Informan pertama yang akan dijelaskan adalah yang memilih warna kuning. Penyebab ketakutan informan ini adalah kehilangan sahabatnya. Pewarnaan yang dipilih oleh informan untuk meluapkan atau menggambarkan perasaan takutnya adalah warna kuning saja.

Mengapa warna yang muncul disaat informan ini merasa takut adalah warna panas? Padahal jika merujuk pada sejarah arti perlambangan warna, maka warna ini merupakan lambang matahari di Mesir. Matahari merupakan lambang kehidupan yang memberikan kehangatan, energi, dan juga waktu di mana orang berakitivitas. Dan jika kita melihat di Cina dan kalangan Kristen Eropa, maka warna kuning adalah warna yang dianggap suci. Tetapi mengapa saat takut malah warna kuning yang muncul?

Pemilihan warna kuning pada informan ini memiliki kesan adanya perasaan penakut, caution, danger, dan tidak stabil. Jika dilihat lebih jauh lagi, maka saya menemukan bahwa ada hubungan antara penyebab informan takut dengan warna, yaitu informan merasakan adanya bahaya (danger) karena akan kehilangan teman. Sehingga dia menjadi was-was dan perasaan takut ini menjadi timbul.

Dari sini dapat disimpulkan bahwa warna kuning yang dipilih oleh informan itu muncul karena dia merasakan adanya bahaya dan rasa takut, tetapi di samping itu, warna ini juga memiliki kesan bahwa dia memiliki harapan. Memiliki harapan yang sangat besar agar sahabatnya tidak dipindahkan sekolah. Perasaan takut yang besar ini juga diimbangi dengan sinar harapan yang besar untuk memandang ke arah positif. Inilah alasan informan memilih warna kuning yang sama sekali tidak terasa suramnya, malah terlihat sangat bersinar. Dari sini saya menyadari bahwa warna yang menunjukkan perasaan takut tidak selalu terkesan suram, sedih, maupun kesepian, tetapi juga bisa menjelaskan penyebabnya dan perasaan lain selain rasa takut, yaitu merasa adanya ancaman dan bahaya.

\section{Pembahasan Simbol yang Digunakan Saat Mood Takut}

Permainan simbol yang akan dibahas adalah simbol-simbol hasil imajinasi informan. Sebenarnya pada gambar informan ini banyak yang menggambarkan keadaan yang sebenarnya, jadi tidak menggunakan imajinasi mereka. Oleh karena itu simbol yang dubahas hanya dibatasi, yaitu simbol-simbol imajinasi informan.

Pada gambar informan yang merasa takut, akan dibahas simbol salib terlebih dahulu. Infoman menggambarkan salib untuk mengungkapkan perasaan takutnya. Dan di sini terlihat bahwa salib ini memiliki makna secara denotatif adalah kayu silang atau gambar garis yang bersilang. Inilah yang disebut tanda pada tingkatan pertama, yaitu denotatif.

Berbicara mengenai salib, maka pertama kali yang akan muncul di benak semua masyarakat adalah sebuah lambang kekristenan. Lambang Kristen identik dengan salib, oleh karena itu di beberapa gereja dan Alkitab (kitab suci agama Kristen) menggunakan tanda tersebut. Salib sebagai lambang sebuah kekristenan ini menandakan bahwa informan ini adalah orang yang beragama Kristen. Ini adalah tanda pada tingkatan kedua, yaitu konotatif atau bisa disebut juga dengan mitos.

Lalu kita gali lagi lebih dalam mengenai salib dan Kristen ini. Di dalam kepercayaan Kristen, salib ini 
adalah sebuah lambang yang memiliki 2 makna yang berlawanan, yaitu makna negatif adalah lambang dari sebuah penderitaan dan pengorbanan. Sedangkan makna positifnya adalah tanda keselamatan. Salib itu sendriri merupakan lambang dari Kristus di mana ia mati di atas kayu salib dan bangkit atas kematian. Kebangkitan Yesus inilah yang memberikan harapan pada orang Kristen akan kehidupan kekal, di mana kematian telah dikalahkan oleh Yesus. Di sini bisa dijelaskan bahwa salib ini memiliki makna yang begitu banyak dan dalam seperti yang telah diuraikan di atas.

Informan yang menggunakan simbol ini sebagai luapan perasaan takut pasti memiliki maksud tersendiri. Di sini salib akan diinterpretasikan dalam berbagai macam arti. Salib ini memiliki makna bagi informan sebagai berikut:

- Salib ini diartikan sebagai sebuah simbol Yesus.

- Yesus adalah sosok yang ia yakini bisa membantu dan menolongnya di saat informan mengalami ketakutan.

- Salib ini membuatnya merasa lebih tenang dengan membayangkan bahwa ada Yesus yang selalu menemaninya.

- Salib itu sendiri juga bisa menjadi ketakutan informan akan sosok Yesus dalam pengertian takut melakukan sesuatu yang berdosa.

Dari sini, terpikir bahwa tanda salib ini memiliki makna yang mendalam bagi informan ini. Relasi tanda dari salib yang paling mendekati konteks dari informan adalah saat di mana dia ingin menceritakan bahwa dia sedang mengalami ketakutan kehilangan seorang teman yang tidak ia ceritakan kepada orang lain tetapi kepada Tuhan. Selain itu informan memiliki pemikiran bahwa hanya Tuhan yang dapat menolongnya.

Ada informan lain yang menarik untuk diinterpretasikan, di mana di dalam gambar informan ini ada satu topik besar yang diangkat olehnya, yaitu mainan (Gambar 7).

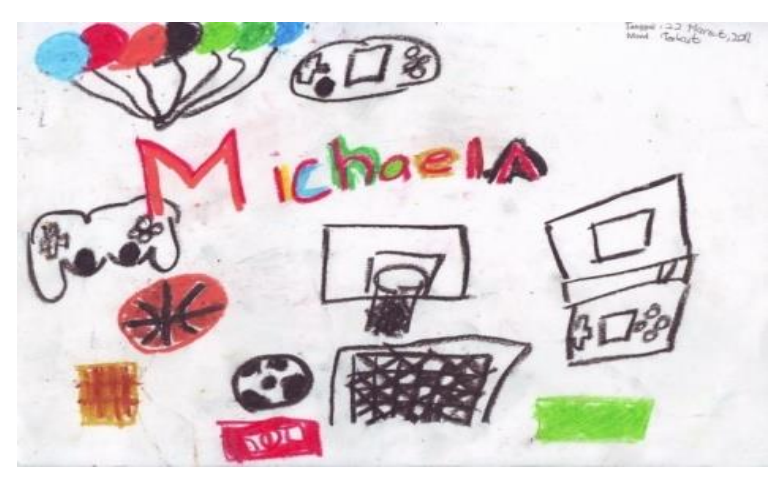

Gambar 7. Gambar Titi saat mengalami mood takut
Mainan yang ada di dalam gambar ini terbagi menjadi tiga kategori atau tema. Tema yang pertama adalah tema mainan modern yang terlihat dari gambar PSP, NDS, dan PS. Lalu tema yang kedua adalah permainan olahraga, yaitu basket dan sepak bola. Tema yang kedua ini dia menggambarkan sebuah "korelasi”" atau hubungan, yaitu ada lapangan basket dan sepak bola, ada juga ring basket dan gawang sepak bola, lalu ada bola basket dan bola sepak. Lalu tema yang ketiga adalah mainan anak-anak, yaitu balon yang berwarnawarni. Balon di sini tidak digambarkan berjumlah 5 seperti lagu "balonku ada lima", tetapi ada 7 buah balon. Walaupun terdiri dari 7 , tetapi warna yang digunakan tidak seperti pelangi juga (mijikuhibiniu). Selain mainan, di sini informan juga menggunakan teks yang bertuliskan namanya sendiri dan juga ada benda lain, yaitu sebatang coklat.

Mainan yang digambarkan pada tema pertama ini memiliki makna bahwa itu adalah mainan kesukaannya yang bisa menghilangkan stresnya. Di sini terlihat bahwa dia ingin lepas dari rasa takutnya yang membuatnya stres, jadi dia menggambarkan benda-benda yang bisa mengurangi stresnya. Terlihat juga dari penggunaan warna pada mainan modern ini adalah hitam dan putih saja, jadi ada rasa tertekan dan takut juga. Di sini akan sedikit dibahas mengapa warna yang dipilih adalah hitam. Anak ini hanya boleh bermain mainan seperti PS itu disaat liburan saja, jadi dia tahu bahwa hal yang bisa mengurangi stresnya ini tidak akan terwujud saat itu. Jadi dia menggambarkan dengan warna hitam dan putih.

Simbol ini memiliki arti yang secara denotatif adalah mainan canggih yang sekarang sangat disukai oleh anak-anak sebagai hiburan dan mungkin banyak yang kecanduan. Tetapi secara konotatif, ini bisa mengartikan bahwa mainan modern itu adalah hasil imajinasi informan yang ingin lepas dan pergi ke dunia lain, yaitu dunia game. Informan ingin lari dari dunia yang nyata karena rasa takutnya tersebut. Ada juga mitos mengenai mainan canggih ini menandakan bahwa jika seseorang bisa menyelesaikan misi yang ada di dalamnya maka akan ada kepuasan dan kebanggan tersendiri. Dari sini terpikir bahwa informan juga ingin menyelasaikan atau mengatasi rasa takutnya agar dia bisa merasa puas dan mungkin ada kebanggan tersendiri jika informan bisa lepas dari rasa takut itu.

Saat anak menggambarkan tema kedua, yaitu permainan olahraga, yaitu basket dan sepak bola beserta alat bermain dan lapangannya, maka terlihat bahwa secara denotatif, anak ini menandakan suka dengan olahraga yang berhubungan dengan 
bola yang memiliki area bermain yang luas. Ini merupakan kesukaan atau hobi informan ini. Olahraga biasanya diidentikkan dengan keringat, sehat, dan bergerak. Karena ada gerakan sehingga menghasilkan keringat, keringat yang keluar sama seperti mengeluarkan racun yang ada di dalam tubuh sehingga badan lebih terasa segar dan sehat. Dari sini saya menginterpretasikan bahwa olahraga ini karena dia ingin melepaskan racun-racun di dalam tubuhnya, yaitu rasa takut itu sendiri.

Lalu melihat lapangan sepak bola dan basket yang luas ini maka interpretasi yang muncul adalah simbol ini sebagai sebuah kebebasan dan kelapangan hati. Kebebasan untuk bertindak atau bermain di sekolah tanpa larangan sehingga dia tidak perlu merasa takut dan kelapangan hati dari orang yang dia takuti agar tidak memarahinya. Perasaan takut ini terkurung dan terlihat dari lapangan yang digambarkan ukurannya sangat kecil, sedangkan bolanya jauh lebih besar. Dari situ kelihatan bahwa anak ini memang memiliki keinginan seperti itu tetapi dia masih terikat dan terbatas.

Jika diperhatikan lagi dengan jelas, maka bola memiliki hubungan dengan "gol" (gawang maupun ring basket) secara seimbang ukurannya, di mana memang mengartikan bahwa dia ingin memasukkan perasaan takutnya ke dalam sebuah wadah agar setelah itu dia tidak perlu takut lagi menghadapi hari esok. Lalu lapangan yang digunakan lebih kecil ukurannya karena informan ingi mengatakan betapa kecilnya kemungkinan dia mendapatkan kebebasan dari hal yang dia lakukan untuk tidak dipermasalahkan.

Tema yang ketiga adalah permainan anak-anak, yaitu balon yang berjumlah 7 buah dengan 7 warna yang berbeda dan terikat menjadi satu. Di sini secara gamblang bisa mengartikan sebuah balon sebagai sebuah benda yang ringan dan memiliki sifat mudah meletus dan juga bisa terbang tinggi.

Tetapi jika diinterpretasikan lebih jauh lagi, maka akan didapati bahwa balon ini melambangkan sebuah kebebasan atau kelepasan, cita-cita yang tinggi, menyerah pada keadaan (mengikuti arus angin), mimpi, dan keceriaan. Dari semuanya ini, maka balon memiliki makna sebagai rasa kelepasan dan kebebasan yang informan mau, di mana dia ingin bebas dari perasaan takut dan ingin menyerah pada keadaan, lalu kembali ceria seperti biasanya tanpa rasa takut. Tetapi jika melihat balon yang terikat antara satu dengan lain di mana melambangkan perasaan takutnya masih belum lepas dari dirnya. Dia ingin menyerah kepada keadaan, tetapi dia tidak mau melepaskan balon tersebut karena ada perasaan ingin membela diri terhadap apa yang dilakukannya. Keceriaan adalah harapan dari informan untuk bisa lepas dari rasa takut dan ceria seperti biasanya.

Kemudian dalam gambar informan juga terlihat adanya teks, yaitu tulisan namanya sendiri yang diwarna dengan berwarna-warni. Dalam satu huruf, informan menggunakan dua warna yang berbeda. Secara langsungakan terlihat nama informan ini maka interpretasi yang muncul adalah dia ingin menyatakan dan mengungkapkan identitas dirinya atau mengenai siapa dirinya. Tetapi dibalik itu, bisa juga diinterpretasikan sebagai sebuah keberadaannya sebagai anak yang ceria dan tidak kenal takut serta berani seperti yang biasanya dikenal di sekolah maupun di rumahnya. Dia sekarang berada dalam suatu kondisi yang tidak seperti biasanya. Nama ini memiliki makna yang dalam di mana ada rasa ingin dikenal. Maka dari sini bisa diinterpretasikan bahwa informan ingin agar orang lain tau perasaannya dan sifatnya yang sebenarnya.

Simbol terakhir yang akan dibahas adalah simbol yang berbeda dari semuanya, yaitu sebatang coklat. Sebatang coklat utuh yang belum dimakan atau dipatahkan untuk dibagi. Coklat adalah makanan yang banyak disukai oleh semua orang karena rasanya yang manis dan enak.

Jika diinterpretasikan lebih dalam lagi, maka akan dibahas sedikit mengenai asal usul dari coklat. Coklat ternyata ditemukan dan dikonsumsi oleh suku kuno, yaitu suku Maya di Amerika. Rasa coklat yang sebenarnya adalah pahit, bukan manis seperti yang kita nikmati sekarang. Rasa manis ditemukan saat seseorang bernama Cortez memasukkan gula kedalam coklat. Dari sini, saya memiliki pandangan bahwa coklat tidak hanya melambangkan sesuatu yang manis, indah, dan nikmat, tetapi juga menandakan kepahitan. Tetapi dibalik kepahitan, Menurut penelitian American Dietetic Association menyatakan bahwa mengkonsumsi coklat bisa membuat otak terasa santai dan tenang karena ada senyawa yang menghasilkan serotonin. (dalam Jodi, 2009)

Coklat yang digambarkan informan dapat dimaknai sebagai obat penenang untuk perasaan takut. Informan menggambarkan coklat karena saat mengkonsumsi coklat, perasaan biasanya lebih tenang dan kepahitan yang ada bisa menjadi manis. Oleh karena itulah ada informan yang menggambarkan demikian.

\section{Analisis Hubungan Elemen Desain dengan Mood Bosan}

Saya mulai memperhatikan satu per satu dari ketiga mood yang saya pilih (takut, marah, dan bosan). Setelah saya perhatikan, ternyata mood 
yang selalu ada pada jurnal gambar informan adalah bosan. Kebosanan karena tidak adanya kegiatan menjadikan mood ini banyak muncul di jurnal anak. Hal inilah yang membuat saya yakin bahwa bosan adalah mood yang paling sering dialami oleh anak-anak.

Tabel 3. Hubungan elemen desain dengan mood bosan

\begin{tabular}{ll}
\hline & \multicolumn{1}{c}{ Bosan } \\
\hline Garis & Lurus (1) dan lengkung (2) \\
Bentuk & Persegi (1) dan lingkaran (2) \\
Warna & Putih (1) \\
& Hijau dan biru (2) \\
& Coklat tua, coklat muda, dan hitam (3) \\
\hline
\end{tabular}

\section{Keterangan}

(1) : Sering muncul dan digunakan

(2) : jarang muncul dan digunakan

(3) : Sangat jarang muncul dan digunakan

Kata-kata seperti "bosan", "BeTe", "malas", "nggak tau mau ngapain", "itu-itu saja”, "nggak ada yang lain", "nggak ada yang menarik", dan lain-lain adalah kata-kata yang sekarang sering muncul untuk mengungkapkan perasaan bosan. Walaupun mengungkapkan perasaan bosan, kata-kata ini juga bisa mengindikasikan perasaan yang lainnya. Di sini akan dijelaskan sedikit mengenai perasaan yang sehubungan dengan bosan ini. Penyebab bosan bisa berbagai macam, yaitu karena rutinitas seseorang, tidak ada hal yang baru atau karena melihat sesuatu yang sama terus setiap hari, tidak ada yang menarik untuk dilakukan, dan akhirnya timbullah kebosanan. Lalu akibat dari bosan bisa bermacam-macam, seperti malas, melamun, mengantuk, atau bahkan tertidur. Hal-hal yang biasanya muncul adalah hal-hal yang terasa santai dan tenang di saat orang merasa bosan. Perasaan yang sangat berbeda dengan takut yang tidak bisa tenang dan marah yang akan meledak-ledak.

Menurut Britton dan Shipley dari University College London, mengungkapkan bahwa rasa bosan memang tidak langsung "membunuh". Tetapi, rasa bosan membuat seseorang cenderung bersikap negatif, seperti kecanduan alkohol, narkotika, dan mendatangkan masalah kesehatan dan psikologis akut. (indonews.org). Dari penjelasan pakar di atas dapat disimpulkan bahwa bosan bisa berakibat buruk.

Ada suatu bahasa yang bisa diketahui saat seseorang sudah mulai bosan berbicara kepada saya, yaitu dari bahasa tubuh. Biasanya saat orang mulai bosan berbicara maka mereka akan menopang dagunya dengan satu atau kedua tangannya. Selain itu mata akan sering melirik ke kiri atau kanan dan jarinya mengetuk-ngetuk tanda tidak sabar dan bosan.
Di sini akan dijelaskan sedikit mengenai mitosmitos seputar bosan. Orang selalu mengatakan jika bosan lebih baik jalan-jalan saja entah kemana, pokoknya jangan dirumah karena nanti bisa semakin bosan. Ada juga orang yang bosan malah berbelanja ke pasar, memasak, dan makan bersama dengan teman untuk menghilangkan kebosanan. Ada juga yang menyarankan untuk mencari hal yang baru yang belum pernah dia ikuti. Tetapi yang sering disarankan dan sedikit memakan biaya adalah berlibur ke pantai, gunung, atau ke tempat yang dia sukai untuk menghilangkan stres. Tempat yang paling sering disarankan oleh orang untuk menghilangkan stres biasanya pantai atau tempat-tempat yang berhubungan dengan alam. Selain itu dari sini bisa disimpulkan bahwa cara menghilangkan bosan adalah dengan melakukan aktivitas yang berbeda dari kesehariannya.

Dari mitos-mitos di atas, bisa ditarik kesimpulan bahwa di saat orang merasa bosan, maka garisgaris yang digunakan adalah garis horizontal, diagonal, dan majemuk. Garis majemuk ini seperti garis spiral, gelombang, dan mungkin yang tak beraturan karena saat bosan, biasanya orang akan malas sehingga garis yang dihasilkan tidak kuat dan memiliki kesan malas. Sehingga garis vertikal kemungkinan jarang terlihat digunakan jika seseorang merasa bosan.

Garis horizontal ini memiliki kesan lemah, tidur, tenang, damai, pasif, kaku dan mati. Sedangkan perasaan bosan biasanya juga tidak memiliki gairah, yaitu energi yang lemah, perasaan sepi, ingin tidur, dan pasif. Sedangkan garis diagonal memiliki kesan tidak tenang dan gerakan yang aktif. Lalu garis majemuk seperti garis berombak memiliki kesan berirama, indah, dinamis, luwes, lemah gemulai di mana terkesan tidak menggunakan power dalam melakukannya, tetapi diperlukan perasaan yang halus, seperti bosan yang biasanya terkesan bingung tidak tau harus berbuat apa dan akhirnya hanya diam saja dan bersantai.

Jika seseorang merasa bosan, maka bentuk yang muncul adalah bentuk-bentuk yang tak beraturan atau yang tidak memerlukan energi begitu banyak. Jadi bentuk-bentuk yang seharusnya digunakan adalah bentuk lingkaran karena menggambarnya lebih mudah dan tidak menghabiskan banyak energi. Bentuk lingkaran ini mempunyai arti Lingkaran ini menggambarkan bahwa anak dalam kondisi emosi yang stabil, adanya kedinamisan, dan melambangkan kehidupan. Bentuk yang dibuat akan cenderung ada lengkungan-lengkungan yang smooth karena terkesan malas dan tidak memerlukan suatu energi yang berlebihan. 
Pemilihan warna juga bisa ditebak dan dilihat dari perasaan seseorang saat itu. Di saat orang merasa bosan, maka warna-warna yang digunakan adalah warna-warna netral dan dingin seperti hitam, putih, biru, dan hijau. Warna hitam memberikan kesan ada sesuatu yang kosong, membosankan, dan sepi. Warna putih memberikan kesan monoton, dingin, sedih, dan hampa. Lalu warna biru mengesankan diam, tenang, dan tidak punya emosi. Lalu warna hijau memberika kesan jenuh, melemahkan pikiran dan fisik, dan kemurungan. Tetapi jika diperhatikan, warna biru dan hijau melambangkan warna dari alam di mana warna ini bisa menghilangkan rasa bosan. Warna biru memberikan kesan harmoni, menyenangkan, bersahabat, santai, impian, air, dan tenang. Jika seseorang melihat laut yang tenang berwarna biru maka perasaan menjadi lebih enak. Begitu juga dengan warna hijau memberikan kesan adanya kesesegaran, harapan, sehat dan sembuh, alami, menyejukkan, dan rileks. Saat orang merasa bosan maka warna hijau dapat membantu orang merasa fresh seperti warna biru yang melambangkan air.

Melihat mitos-mitos seputar bosan secara lisan yang banyak disampaikan oleh masyarakat maupun pakar-pakar psikologi dan realita yang ada di dalam kehidupan kita, sekarang kita akan memperhatikan beberapa ekspresi dari kebosanan yang mendukung mitos-mitos seperti yang dijelaskan di atas. Ekspresi ini berupa gambar yang bisa lebih menguatkan dalam penjelasan-penjelasan di atas, antara lain:

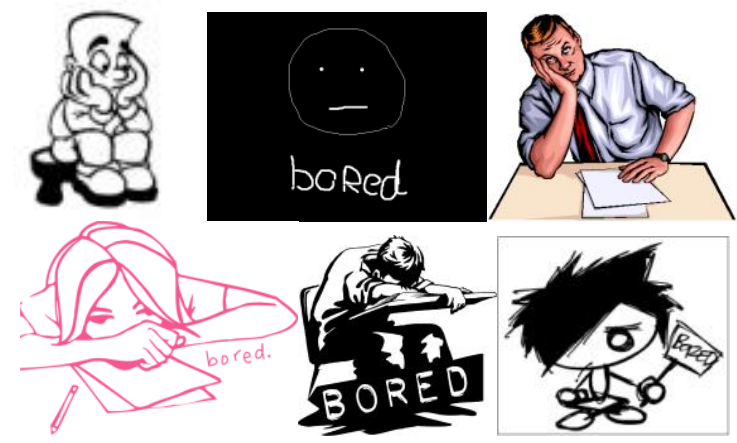

Sumber: http://sneversaynever.blogspot.com/2010/10/boredom.html; http://melurve.blogspot.com/2011/03/bored-imbored-to-death.html ; http://mazali.wordpress.com/2008/ 12/03/bored/ ; http://yosuakristianto.wordpress.com/2010/ 03/09/bored-post/

Gambar 8. Berbagai macam ekspresi bosan

Di sini dapat disimpulkan bahwa secara mitos, saat orang merasa bosan, maka elemen desain yang digunakan adalah sebagai berikut:

- Garis yang digunakan cenderung menggunakan garis lurus seperti horizontal dan diagonal, selain itu juga menggunakan garis majemuk.
- Bentuk yang sering digunakan untuk menggambarkan kebosanan adalah bentuk lingkaran atau bentuk yang mungkin tidak beraturan.

- Warna yang digunakan adalah warna-warna netral dan dingin seperti hitam, putih, biru, dan hijau.

\section{Pembahasan Penggunaan Garis Saat Mood Bosan}

Kecenderungan informan dalam menggunakan garis saat merasa bosan adalah garis lurus. Gari lurus yang cenderung digunakan adalah vertikal, horizontal, dan diagonal. Dari cara penggoresan krayonpun cenderung menggunakan garis yang membentuk diagonal dan horizontal. setelah itu baru goresan yang mangarah vertikal dan tidak teratur. Garis yang digunakan informan cenderung garis lurus, sedangkan garis lengkung juga digunakan tetapi tidak terlalu menonjol. Jadi, garis yang akan dibahas adalah garis lurus.

Penggunaan garis diagonal dan horizontal memang memiliki kesan yang berhubungan dengan rasa bosan di mana orang yang merasa bosan memang mengakibatkan seseorang merasa ngantuk dan tertidur, ataupun ingin melakukan aktivitas yang berbeda dari biasanya sehingga ada garis diagonal yang muncul sebagai gambaran keinginan memiliki aktivitas yang lain.

Saya akan membahas mengenai informan yang ternyata cenderung menggunakan garis vertikal saat mengalami kebosanan. Padahal garis vertikal ini memberikan kesan kuat, tegas, tegar, dan teguh hati. Di sini tidak terlihat adanya hubungan dengan perasaan bosan, tetapi saya ingin menjelaskan bahwa penggunaan garis ini tidak selalu menggambarkan perasaan bosannya, tetapi juga bisa menggambarkan bahwa dia bosannya karena tidak ada teman dan belajar.

\section{Pembahasan Penggunaan Bentuk Saat Mood Bosan}

Bentuk yang digunakan para informan ternyata cenderung pada bentuk persegi, yaitu persegi panjang dan juga ada yang jajar genjang. Persegi ini menggambarkan adanya perasaan yang kesal atau marah dalam tingkatan yang rendah. Tetapi di saat bosan, informan ini cenderung tidak ada rasa marah di dalamnya selama saya mewawancarai. Informan biasanya bosan dalam taraf yang mereka menganggur dan tidak tahu harus berbuat apa dan ada juga yang bosan karena harus belajar. Bosan karena belajar bisa juga ada perasaan kesal karena merasa capek dan lelah atau tidak bisa mengerjakannya. Perasaan ini membuat informan menghasilkan bentuk persegi. Lalu jika kita melihat ke 
dalam perasaan yang lainnya, mereka menggambarkan persegi karena memang gambar realita yang ada disekitarnya memang berbentuk persegi. Karena jika diperhatikan dengan seksama, maka ruang tamu, ruang keluarga, ruang kamar saya itu memang banyak benda-benda yang berbentuk persegi.

Dari sini dapat disimpulkan bahwa penggunaan bentuk tidak selalu menggambarkan perasaan dari seseorang. Di saat mereka menggambar, saya harus memastikan dahulu apakah itu adalah gambar suasana saat dia menggambar atau memang gambar sebuah imajinasi saja. Hal ini mempermudah untuk meneliti gambar tersebut dalam hubungannya dengan bentuk.

\section{Pembahasan Penggunaan Warna Saat Mood Bosan}

Warna yang digunakan pada saat informan merasa bosan cenderung warna putih yang digunakan. Lalu warna yang digunakan lainnya adalah warna hijau dan biru. Warna yang digunakan lainnya tetapi tidak terlalu sering adalah warna dari keluarga coklat, dan hitam.

Warna putih ini cenderung digunakan karena memberikan kesan bahwa seseorang ini merasa bosan karena sesuatu yang monoton sehingga mereka ingin mencari sesuatu yang baru, tetapi tidak tahu apa yang harus dilakukan untuk mendapatkan kegiatan yang menarik. Warna ini memiliki kesan sepi dan tenang di mana saat bosan, maka informan cenderung tidak melakukan kegiatan apa-apa. Lalu warna hijau dan biru memang terkesan bahwa mereka sedang jenuh dan juga menginginkan sesuatu yang lebih berwarna dan menarik untuk menghilangkan kebosanan mereka dan warna keluarga coklat itu memberikan kesan kuno dan jika sering-sering menggunakan lama itu, maka akan terasa bosan. Lalu warna hitam memang melambangkan sesuatua yang membosankan.

Ternyata warna yang digunakan di saat orang merasa bosan, secara mitos dan keadaan realitanya memang sama, yaitu sama-sama banyak menggunakan warna netral dan dingin di dalam pemilihan warnanya. Warna yang digunakan memang ada yang hasil warna dari imajinasi karena secara realita warnanya tidak seperti itu, tetapi ada juga yang warnanya merupakan warna imajinasi yang merupakan warna yang dipilihnya berdasarkan perasaannya saat itu.

Di sini akan disinggung sedikit mengenai ruang kosong yang disisakan saat informan merasa bosan cenderung banyak. Saat informan merasa bosan, maka ruang kosong yang tersisan sekitar 40-60\% dari bidang yang ada. Dari semua informan yang ada hanya ada 1 gambar yang penuh dan 1 gambar yang sedikit sekali ruang kosongnya sekitar 5\% saja.

Ruang kosong yang sedikit dan penuh ini menggambarkan bahwa saat mereka bosan, mereka memiliki sebuah harapan untuk bisa mengatasi rasa bosannya dengan cara bermain atau mengerjakan sesuatu yang lain. Informan pertama memang menggambarkan penuh karena ada kainginan dan harapan seperti itu, tetapi informan ini menggambarkan perasaan bosannya di hari yang sama tetapi berbeda waktu dengan menggunakan ruang kosong sekitar $45 \%$ yang menandakan dia tidak menemukan permainan yang asik untuk menghilangkan kebosanannya sehingga informan menggambar lagi perasaan yang sama di hari yang sama. Sedangkan informan yang satunya lagi memang jarang ada perasaan bosan karena memang dia selalu ada kegiatan. Dari sini saya tahu bahwa memang dia memiliki banyak kegiatan yang bisa menghilangkan bosannya sehingga ruang kosong yang tersisanya hanya sedikit saja, yaitu $5 \%$ saja.

\section{Pembahasan Simbol yang Digunakan Saat Mood Bosan}

Simbol-simbol yang terdapat pada informan adalah sebuah buku dan TV yang digambarkan sebuah pemandangan gunung. Kedua simbol yang dapat ditemukan di dalam gambar-gambar informan saat mengalami bosan yang tidak sesuai dengan realita. Saya akan menjelaskan arti dari simbol ini untuk menyatakan perasaan bosan. Lalu ada juga yang ingin saya bahas mengenai simbol dari papan catur yang digambarkan sebagai lantai padahal di rumahnya semuanya menggunakan karpet berwarna abu-abu.

Pertama saya akan membahas simbol pada informan pertama yang menggambarkan sebuah buku. Buku yang digambarkan di sini bukan buku biasa, tetapi sebuah Alkitab. Memang digambar ini tidak ada simbol-simbol yang menyatakan bahwa itu adalah sebuah Alkitab, tetapi saat wawancara didapati bahwa itu adalah sebuah Alkitab. Secara literal Alkitab dapat diartikan sebagai buku atau kitab suci umat yang beragama Kristen atau Katolik. Ini adalah makna denotatif dari Alkitab.

Ada makna lain dari Alkitab yang bisa dijabarkan. Alkitab disebut juga dengan injil, yaitu kabar baik. Selain itu Alkitab juga memiliki hubungan dengan bosan. Bagi beberapa orang, teks yang sangat 
banyak dan panjang merupakan sesuatu yang membuat orang bosan membacanya, khususnya bagi para desain yang suka bermain-main dengan gambar, layout, atau yang tidak terlalu banyak teks. Oleh karena itu Alkitab juga bisa menjadi suatu hal yang membosankan bagi beberapa orang yang memang tidak suka teks banyak atau mungkin tidak memiliki motivasi membacanya. Selain itu anak-anak usia 8-12 tahun biasanya masih belum begitu paham mengenai Alkitab.

Lalu acara TV yang digambarkan oleh informan dengan sebuah gunung dengan matahari yang bersinar di pinggir kanan atas dan langit yang berwarna biru. Acara ini dilihat sebagai "pemandangan alam" khususnya adalah pemandangan gunung. Pemandangan gunung adalah suatu keadaan alam yang berada di gunung. Secara denotatif, pemandanga alam adalah keadaan alam yang indah dan enak dipandang. Selain itu gunung biasanya adalah tempat yang sering didatangi oleh orang untuk berekreasi ataupun yang ingin mendaki.

Gunung memiliki makna lain, yaitu berbicara mengenai keinginan untuk lebih dekat dengan sang Khalik Pencipta. Berbicara mengenai gunung, maka akan berbicara suatu tempat yang dianggap suci dan keramat di mana para petinggi agama tinggal dan beribadah. Gunung juga dimaknai dengan sesuatu yang bersifat spiritual.

Dari sini saya melihat ada suatu pola yang selalu sama digunakan saat orang membuat gambar pemandangan saat merasa bosan selalu menggambarkan gunung. Dari sini maka dapat diinterpretasikan bahwa informan ini hanya mengambil makna secara denotatif, yaitu pemandangan alam yang dia tonton agar tidak bosan. Lalu berbicara mengenai makna lain yang mungkin tidak disadari informan adalah keinginannya untuk berlibur melepaskan rasa bosan ke tempat-tempat yang berhubungan dengan alam. Ada rasa petualangan yang muncul yang menjadi harapan dan keinginan informan agar dia memiliki kegiatan lainnya yang menarik dan berbeda dari keseharian.

Lalu saya akan membahas mengenai papan catur yang merupakan lantai pada rumah. Dia menggambarkan seperti catur karena dia ingin bermain dan melepaskan rasa bosannya. Catur di sini secara literal diartikan sebagai sebuah permainan yang dimainkan oleh dua orang dengan papan catur dan buah catur. Permainan ini tidak bermain seperti ular tangga atau monopoli yang tergantung dari keberuntungan kita mengkocok dadu, tetapi ini permainan yang benar-benar menggunakan otak dan logika. Jadi bisa diinterpretasikan bahwa saat informan ini bosan, maka yang ada di benaknya adalah permainan. Selain itu informan ini memang sepertinya menyukai permainan sehingga di dalam gambarnya rata-rata ada mainan di dalamnya.

Catur ini memiliki makna konotasi, yaitu kecerdikan, akal, teka-teki, dua pilihan, dan kebingungan. Di sini saya ingin menginterpretasikan bahwa informan ini adalah anak yang banyak akal dan kreatif serta suka bermain. Tetapi didalam kecerdikannya dan kekreatifannya, dia sekarang berada di dalam sebuah papan catur dan bingung mau melangkah kemana karena dia tidak tahu mana yang harus dia lakukan saat itu.

\section{Hierarki Penggunaan Elemen Desain}

Di saat mood anak muncul, maka ada hierarki yang bisa disimpulkan dari penggunaan elemen desain yang cenderung digunakan oleh anak. Oleh karena itu, saya akan membahasnya di sub-bab berikut ini.

\section{Hierarki penggunaan elemen desain dan mood marah}

Gambar ini memberikan gambaran mengenai hierarki penggunaan elemen desain yang cenderung digunakan oleh informan.

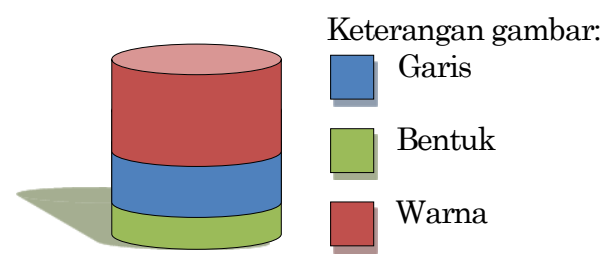

Gambar 9. Hierarki penggunaan elemen desain terkait dengan mood marah

Gambar 9 menyatakan bahwa di saat informan merasa marah, maka perasaan marahnya itu lebih banyak diluapkan atau diuangkapkan melalui warna dibandingkan kedua elemen lainnya. Lalu penggunaan garis dan bentuk sebenarnya memiliki perbandingan nilai 50-50, tetapi saya lebih cenderung menilai garis lebih mengungkapkan perasaannya daripada bentuk. Alasannya adalah karena garis juga terlihat dari goresan krayonnya di mana saat informan marah, maka garisnya berbeda dan juga garis-garis outline juga terkadang memiliki makna adanya persaingan. Tetapi susah untuk melihat ungkapan marah melalui bentuk karena bentuk yang banyak digunakan oleh informan adalah bentuk-bentuk nyata dari apa yang mereka lihat saat itu. Oleh karena itu bentuk kurang bisa mengungkapkan perasaan informan.

Dari sini saya mendapati bahwa saat menginterpretasi gambar, dari ketiga elemen ini yang bisa kita perhatikan terlebih dahulu adalah warna, baru setelah itu garis, dan bentuknya. 


\section{Hierarki penggunaan elemen desain dan mood takut}

Perasaan takut pada informan di saat menggambar memiliki kecenderungan untuk menggunakan elemen desain tertentu sebagai fokus utama. Adanya hierarki yang terlihat pada gambar dibawah ini mempermudah mengetahui kecenderungan penggunaan elemen pada saat seseorang merasa takut.

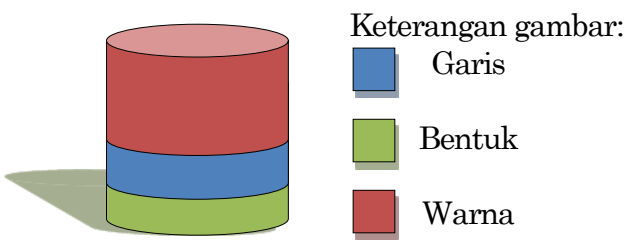

Gambar 10. Hierarki penggunaan elemen desain terkait dengan mood takut

Ternyata warna tetap merupakan elemen yang paling mudah menggambarkan perasaan informan saat membuat sebuah gambar. Garis dan bentuk sebenaranya pada informan kurang terlihat dengan jelas. Tetapi lagi-lagi saya memiliki garis sebagai elemen yang lebih bisa meluapkan perasaan takut daripada bantuk karena garis yang digunakan pada saat takut terkadang memiliki perbedaan dengan mood lainnya.

\section{Hierarki penggunaan elemen desain dan mood bosan}

Bosan merupakan mood terakhir yang ada pada penelitian ini. Dari kesimpulan hierarki mood marah dan takut, saya menebak bahwa pada saat bosanpun yang terlihat adalah dari penggunaan warna. Tetapi apakah benar susunannya akan sama? Dari sini saya ingin memperlihatkan hierarki dari perasaan bosan dalam menggunakan elemen desain bisa dibaca dibawah ini.

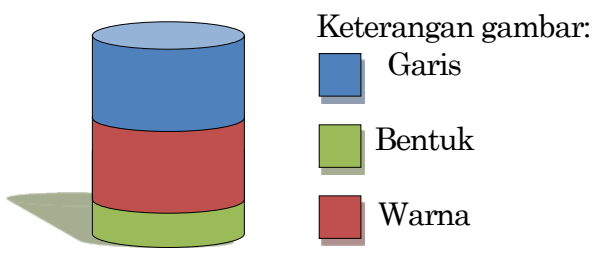

Gambar 11. Hierarki penggunaan elemen desainterkait d engan mood bosan

Setelah diperhatikan dengan seksama lagi, maka sebenarnya antara penggunaan garis dan warna itu sama-sama menunjukkan perasaan bosan. Garis yang dimaksud memang lebih ke arah goresan krayonnya di mana terasa sekali bahwa informan sedang bosan. Warna juga mampu meluapkan perasaan bosannya, tetapi terkadang daripada warna yang digunakan, lebih mudah melihat penggunaan ruang kosong. Ruang kosong yang banyak biasanya menandakan bahwa seseorang sedang merasa bosan. Tetapi warna di sini kurang bisa meluapkan perasaan bosannya. Lalu yang terakhir adalah elemen desain yang memang tidak menonjol. Bentuk ini tidak menggambarkan karena memang kebanyakan mereka menggambarakan suasana nyata di mana mereka berada saat itu.

Saat bosan, maka pertama kali yang dilihat adalah garis dan warna. Bentuk dilihat jika bentuk yang digunakan mungkin hasil imajinasi dan bukan menjadi sesuatu yang nyata ada saat mereka mengalami mood tersebut.

\section{Penggunaan Simbol}

Simbol pada penelitian ini saya batasi khusus untuk objek yang saat informan menggambar, tidak menggambarakn suasana beserta objek-objek yang ada, tetapi simbol yang saya maksud adalah sebuah tanda yang dibuat dari hasil imajinasi mereka dan tidak berada saat mereka menggambar.

Simbol memang jarang digunakan oleh informan untuk mengungkapkan perasaannya, tetapi ada beberapa informan yang suka bermain dengan simbol. Di sini simbol bisa menjadi fokus pertama kita untuk menginterpretasi. Mengapa saya berkata demikian? Karena pada anak-anak usia 8-12 tahun yang memang mulai memperhatikan ciri-ciri dari benda. Bagian-bagiannya mulai ditangkap walaupun belum secara keseluruhan. Pada usia ini, fantasi anak mulai berkurang dan berpikir lebih rasional. Oleh karena itu jika anak-anak usia ini membuat sebuah simbol, maka seharusnya hal tersebut bisa diinterpretasi terlebih dahulu sambil melihat warna yang digunakan dalam simbol tersebut dan mulai merembet ke elemem desain lainnya.

\section{Simpulan}

Adanya hubungan gaya menggambar anak dengan usia anak. Anak-anak usia 8-12 tahun memang merupakan usia di mana daya imajinasi atau fantasi berkurang karena mulai berpikir secara rasional dan memperhatikan ciri-ciri benda. Oleh karena itu informan di sini lebih banyak menggambarkan sesuatu yang sesuai dengan apa yang mereka.

Melihat usia anak yang diteliti maka elemen yang paling sering kita gunakan untuk menginterpretasi adalah warna. Setelah warna barulah kita melihat garis (dalam arti goresan) yang digoreskan pada 
bidang. Bentuk merupakan alternative paling akhir untuk dilihat karena memang anak usia 8-12 tahun sudah mulai berkurang imajinasinya, sehingga bentuk yang digambarkan adalah "real" dan tidak terlihat "abstrak" atau yang lainnya.

Cara mengungkapkan atau meluapkan perasaan informan bisa dengan berbagai macam elemen desain atau hal lainnya, seperti:

- Melalui warna

- Melalui garis atau goresan

- Melalui bentuk

- Melalui warna dan garis

- Melalui warna dan bentuk

- Melalui warna, garis, dan bentuk

- Melalui simbol dan warna yang digunakan

- Melalui ruang kosong yang disisakan

Jadi, kita perlu melihat dengan baik elemen apa yang digunakan informan untuk meluapkan perasaan mereka. Karena tidak semua elemen mereka gunakan untuk meluapkan perasaan, tetapi bisa dengan satu elemen saja. Selain itu kita harus mengenali karakteristik menggambar anak dan keseharian mereka serta apa penyebab dibaliknya.

Elemen desain yang banyak digunakan mengungkapkan perasaan informan adalah warna. Selain mengungkapkan perasaan, warna juga bisa menceritakan akibat yang mereka rasakan pasca mood tersebut. Jadi bukan menceritakan moodnya, tetapi akibat yang terjadi karena mood tersebut.

Karakteristik dari informan memang berbeda-beda jika ingin diteliti lebih dalam lagi. Saya akan melihat dan menjelaskan secara singkat beberapa sudut pandang yang digunakan informan dalam menceritakan keseluruhan mood yang terjadi padanya, yaitu:

- Perasaan mood biasanya digambarkan melalui warna atau garis

- Penyebab mood yang digambarkan dari bentuk atau benda yang ada

- Akibat dari mood digambarkan melalu warna dan garis

- Permainan simbol menggambarkan siapa diri mereka dan apa yang mereka harapkan untuk dilakukan saat mood tersebut muncul.

- Ruang kosong yang disisakan bisa menandakan bahwa informan sedang bosan, tetapi ada juga yang marah. Oleh karena itu, sebagai orang tua, peneliti, atau para guru harus melihat hasil gambar sebagai satu kesatuan dan rutin melihat karakteristik serta gaya gambar dari anak.

Dalam penggunaan elemen desain sesuai dengan mood yang dialami oleh informan, maka dapat disimpulkan bahwa di saat informan mengalami mood marah, maka garis yang cenderung digunakan adalah garis-garis lurus seperti diagonal dan zig-zag, bentuk yang digunakan adalah bentuk persegi dan lingkaran, sedangkan warna yang cenderung digunakan adalah warna merah, jingga, coklat muda, biru dan hitam.

Pada saat informan mengalami mood takut, maka kecenderungan elemen desain yang digunakan adalah garis lurus seperti vertikal dan horizontal, bentuk persegi dan lingkaran, warna hitam dan putih.

Pada saat informan merasa bosan, maka elemen desain yang dipilih cenderung menggunakan garis lurus seperti diagonal dan horizontal, bentuk persegi dan lingkaran, warna putih, hitam, dan biru.

Simbol yang dibuat secara tidak sadar itu muncul atau digambarkan karena pengalaman-pengalaman mereka. Di saat anak usia 8-12 tahun menggambarkan sebuah simbol, beberapa tak paham dengan filsafat ataupun makna tersembunyi dibalik simbol, tetapi mereka lebih banyak menggunakan hasil observasi mereka terhadap benda sehingga menghasilkan simbol tertentu (ingat lagi bahwa anak usia 8-12 tahun mulai berpikir rasional). Jadi menurut saya simbol yang digunakan muncul karena ada suatu pengalaman atau pengetahuan yang mereka tahu dari simbol tersebut.

Kesimpulan mengenai teori dan penelitian ini adalah bahwa teori memang bisa dijadikan acuan dalam menginterpretasi gambar anak melalui elemen-elemen desain, tetapi tidak semua teori "cocok" dengan beberapa kasus tertentu karena ada faktor lainnya, yaitu faktor pola pikir anak, pengalaman anak, pengetahuan anak, dan faktor eksternal seperti tempat dia menggambar, pencahayaan, ataupun yang lain.

Mitos-mitos yang beredar dan beberapa hal yang bersifat konvensional ternyata tidak selalu menjadi ideologi dari anak tersebut. Alasannya menurut saya adalah karena ada ajaran-ajaran yang sudah diajarkan oleh kedua orang tuanya mengenai halhal tertentu sehingga hal tersebut yang lebih tertanam pada anak dibandingkan mitos yang ada. Selain itu kebiasaan anak juga bisa menjadi ideologi bagi mereka sendiri.

\section{Daftar Pustaka}

Barrett, Terry (1994). Principles of Interpreting Art - Art Education, 47(5). Diunduh 23 Februari 2011 dari http://www.terrybarrettosu.com/ pdfs/Barrett\%20(1994)\%20Principles\%20for \%20Interpreting\%20Art.pdf 
Barthes, Roland. (1973). Elements of Semiology. Trans. Annette Lavers and Colin Smith. New York: Hill and Wang.

Dameria, Anne. (2007). Color Basic. Jakarta: Link Match Graphic.

Jodi, Kevin Editha. (2009, Mei 03). Asal Usul Cokelat. Pesan disampaikan dalam http://kevinonly. blogspot.com/2009/05/asal-usul-cokelat-1001asal-usul.html
"Ketidaktahuan Orang Tua Sebabkan 'Generasi Stres'” Kapanlagi.com 27 November 2010. <http://berita.kapanlagi.com/pernik/ketidakta huan-orang-tua-sebabkan-generasi-stres. html>

Mendatu, Achmanto. (11 Juli 2009). Seputar Emosi Takut. Psikologi-online.com. dari <http://psikologi-online.com/seputar-emosi-takut>

Nazir. (2009). Metode Penelitian. Ed. Risman Sikumbang. Bogor: Penerbit Ghalia Indonesia. 


\section{Lampiran}

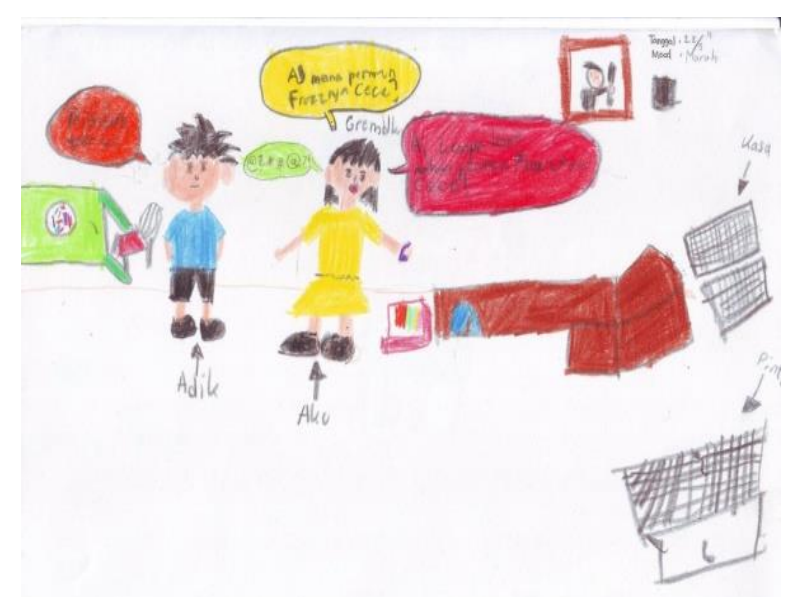

Jurnal pertama Jane saat mengalami mood marah
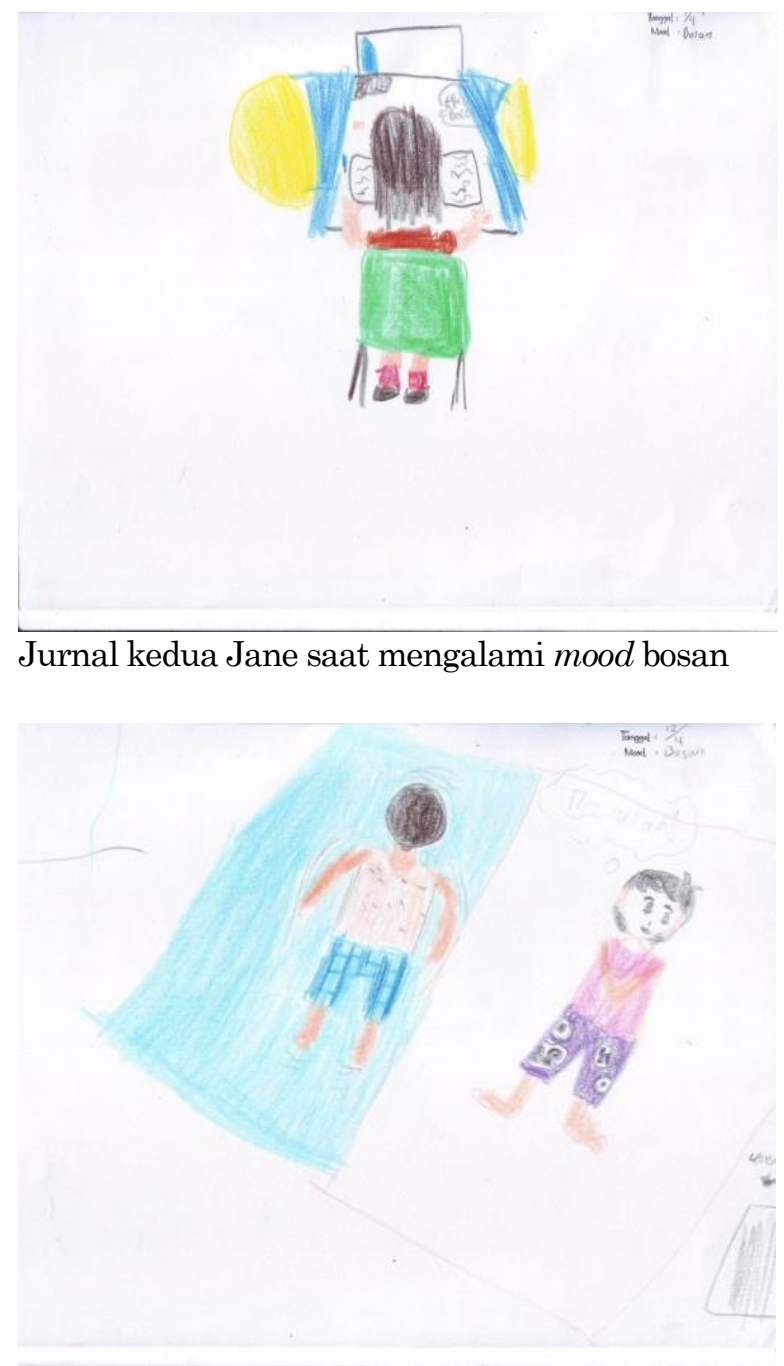

Jurnal ketiga Jane saat mengalami mood bosan

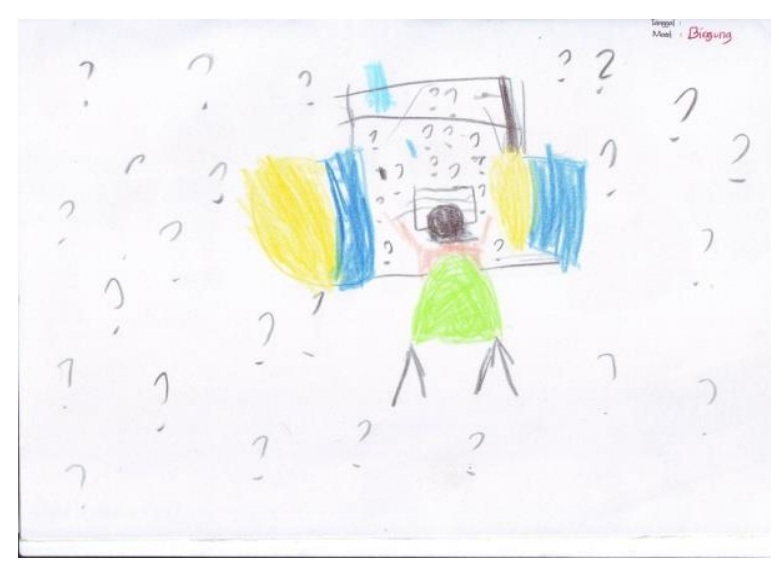

Jurnal keempat Jane saat mengalami mood bingung

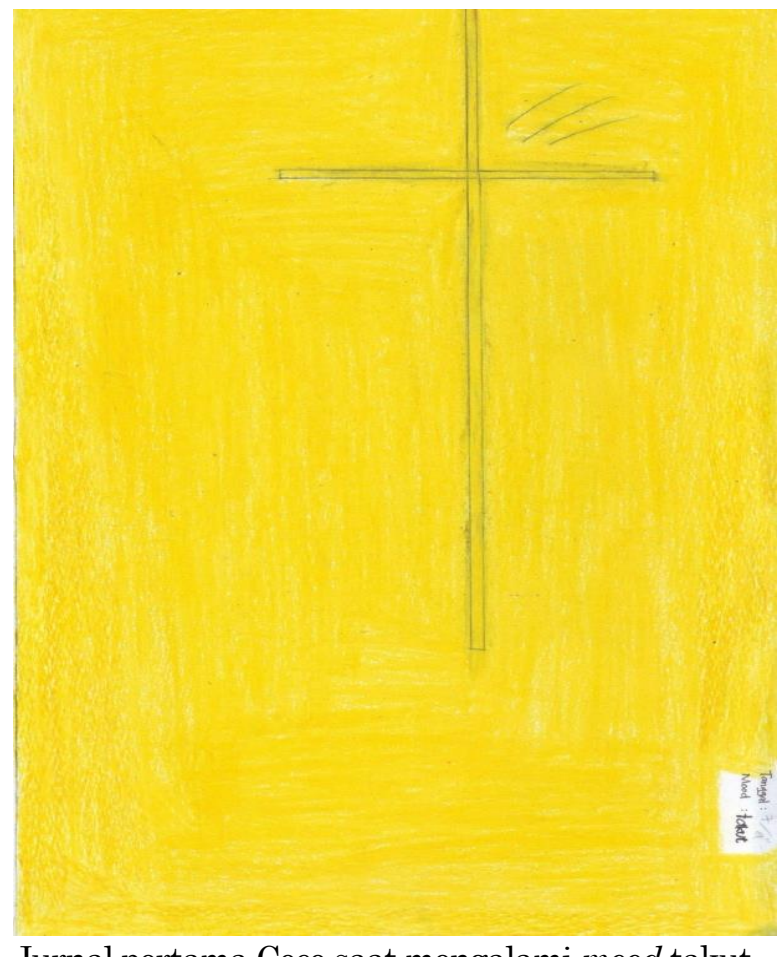

Jurnal pertama Cece saat mengalami mood takut

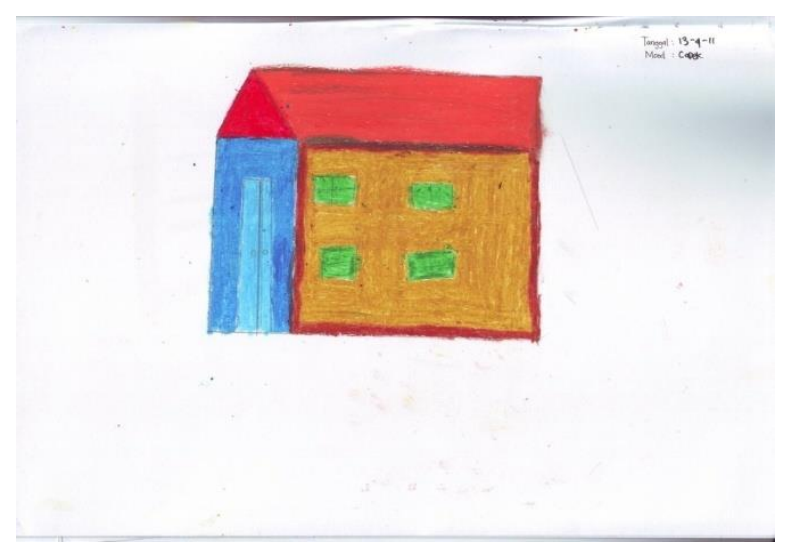

Jurnal kedua Cece saat mengalami mood capek 


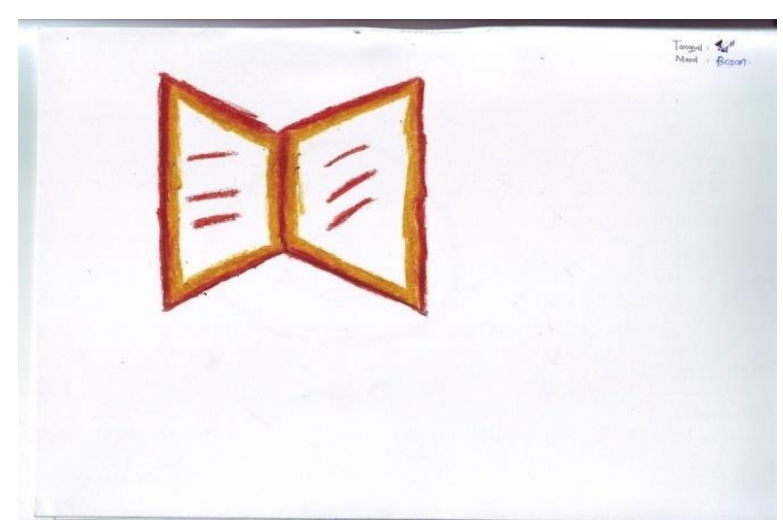

Jurnal ketiga Cece saat mengalami mood bosan

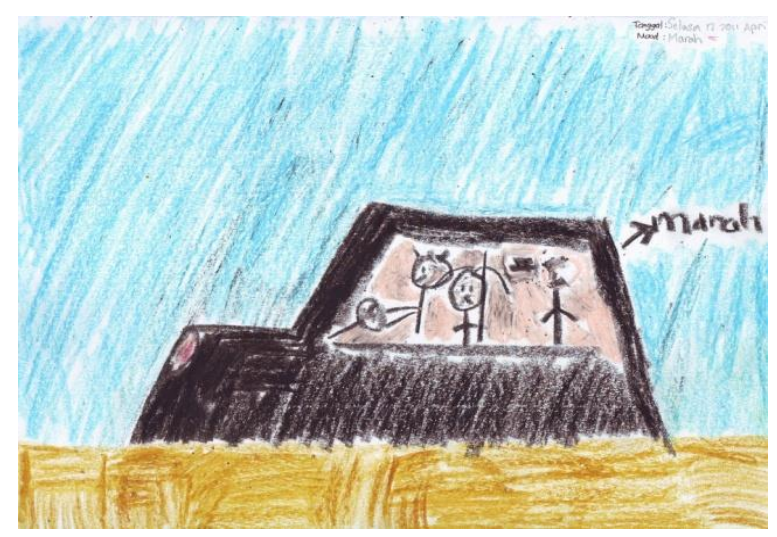

Jurnal pertama Jelly saat mengalami mood marah

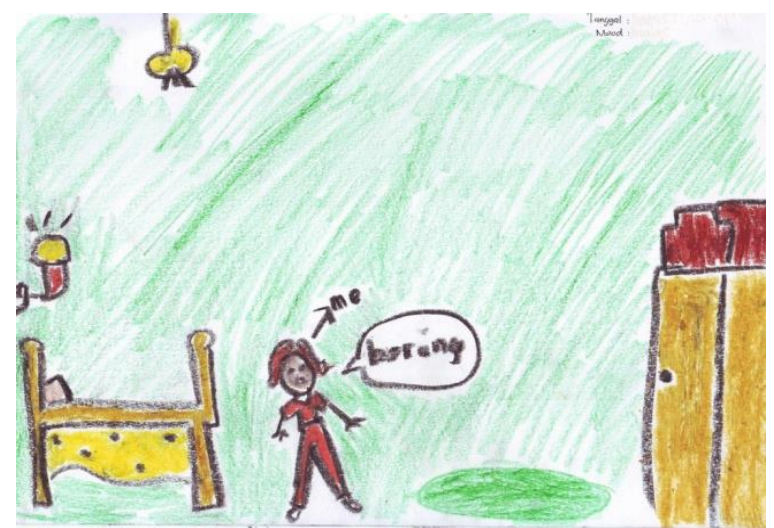

Jurnal kedua Jelly saat mengalami mood malas

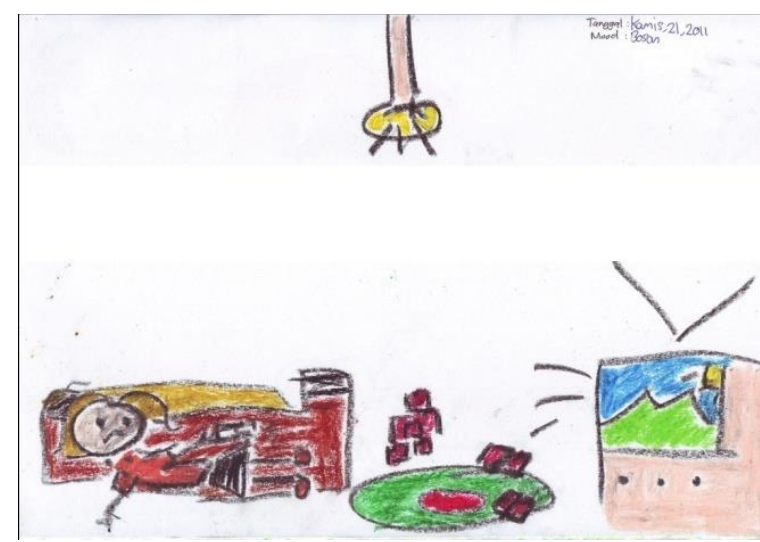

Jurnal ketiga Jelly saat mengalami mood bosan

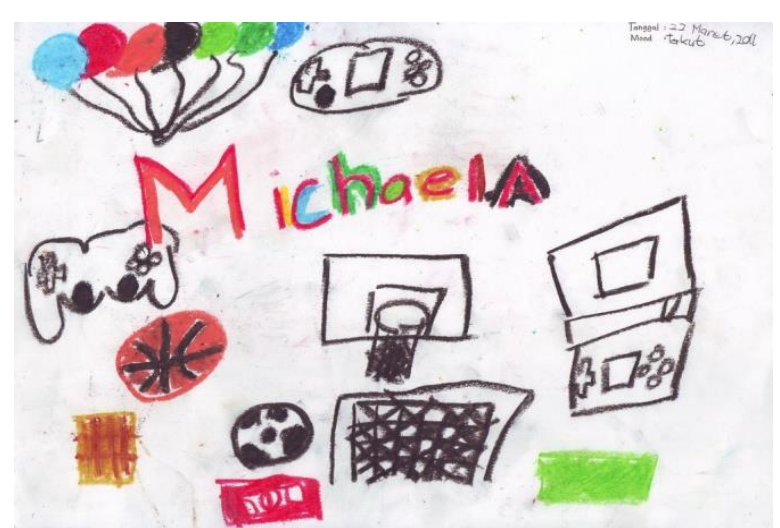

Jurnal pertama Titi saat mengalami mood takut

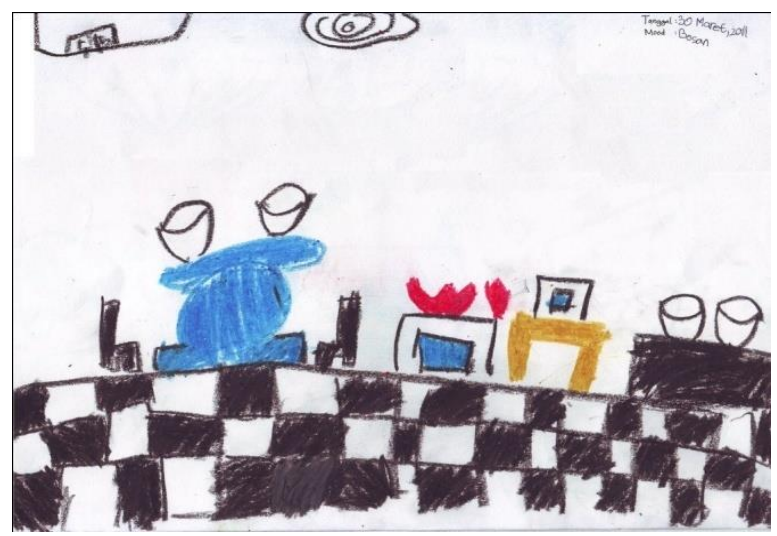

Jurnal kedua Titi saat mengalami mood bosan

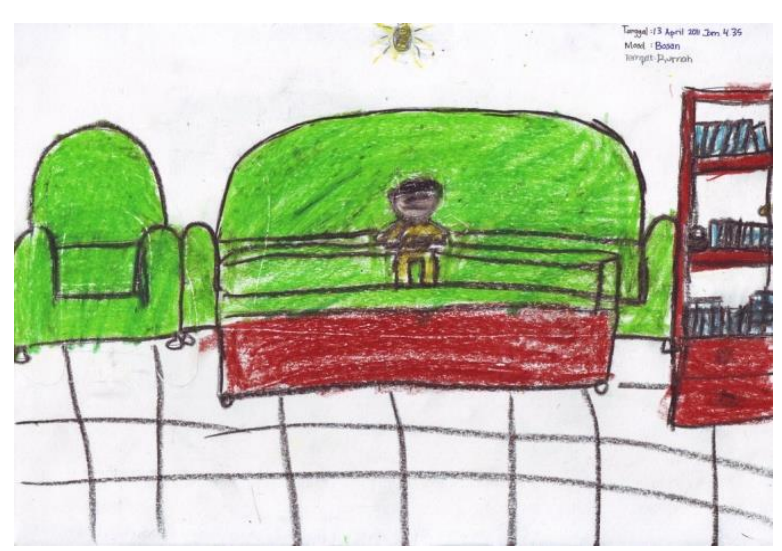

Jurnal pertama Jim saat mengalami mood bosan

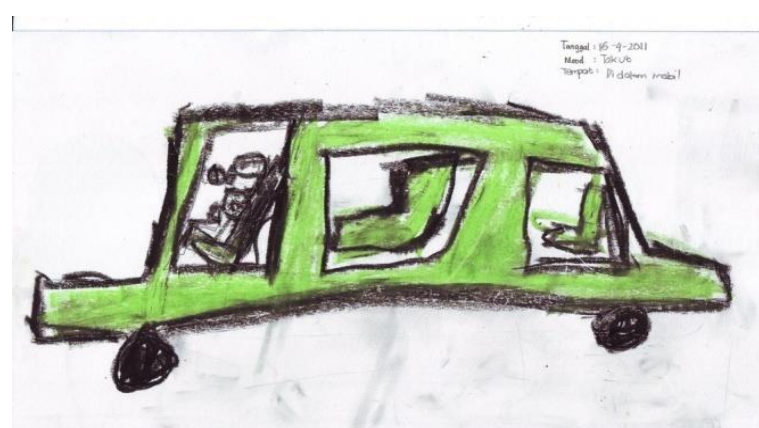

Jurnal kedua Jim saat mengalami mood takut 